\title{
Investigations of the relics and altar materials relating to the apostles St James and St Philip at the Basilica dei Santi XII Apostoli in Rome
}

\author{
Kaare Lund Rasmussen ${ }^{1 *}\left(\mathbb{0}\right.$, Johannes van der Plicht ${ }^{2}$, Jacopo La Nasa ${ }^{3}$, Erika Ribechini ${ }^{3}$, \\ Maria Perla Colombini ${ }^{3}$, Thomas Delbey ${ }^{4}$, Lilian Skytte ${ }^{1}$, Simone Schiavone ${ }^{5}$, Ulla Kjær ${ }^{6}$, Poul Grinder-Hansen ${ }^{6}$ \\ and Lautaro Roig Lanzillotta ${ }^{7}$
}

\begin{abstract}
Two types of materials were sampled as part of an investigation of the relics of the Holy Catholic Church of the Apostles St Philip and St James in the Basilica dei Santi Apostoli in Rome: bone- and mummy-materials and architectural samples. The analyses encompassed radiocarbon dating, thermoluminescence dating, gas and liquid chromatographic separation with mass spectrometric detection, X-Ray fluorescence, X-Ray diffraction, inductively coupled plasma mass spectrometry, Raman spectroscopy, and Fourier transform infrared spectroscopy. The results show that the samples were subjected to a number of conservational and exhibition-related treatments. The alleged femoral bone of St James was dated between AD 214 and 340 (20 confidence), which shows that this cannot be the bone of St James. An encrustation found in a canal in the reliquary in the high altar construction showed the presence of heavily oxidized rapeseed oil, which was radiocarbon dated between AD 267 and 539 ( $2 \sigma$ confidence), and a ceramic shard also found in the high altar construction was TL-dated to AD 314-746 (2 $\sigma$ confidence). The two latter dates are consistent with a translation of the relics following the erection of the church at the time of Pope Pelagius I in AD 556-561.
\end{abstract}

Keywords: Relics, St James, St Philip, Basilica dei Santi XII Apostoli, Radiocarbon, TL, Chemical analyses

\section{Introduction}

The Church

The present Santi XII Apostoli church was built in the third quarter of the 6th Century AD. The concept $[1,2]$ that a basilica built by pope Iulius (337-353) near Trajan's Forum can be identified as a direct predecessor of the Ss Apostoli has been questioned recently [3-5]. There are, however, historical-yet not archaeological-indications that the new church dedicated to the apostles Philip and

\footnotetext{
*Correspondence: klr@sdu.dk

${ }^{1}$ Institute of Physics, Chemistry and Pharmacy, University of Southern

Denmark, Campusvej 55, 5230 Odense M, Denmark

Full list of author information is available at the end of the article
}

James was really built on approximately the same place as the basilica built by pope Iulius and that it took over its role as an episcopal church and as a station church $[6$, 7]. An inscription which is now built into the vestibule of the church, is misleading as it claims that a church was founded by Emperor Constantine in honour of the twelve apostles. But this inscription is of a much later date: epigraphical evidence points to the 14th Century, and the dedication to all twelve apostles is anachronistic. The latter was not practiced until the 10th Century. A titulus church in Rome named "Titulus Apostolorum" appeared on a list from a papal synod in 499 [8], but the designations of the titulus churches at that time were often quite different from the names later used, and in this case the
Springer Open

(c) The Author(s) 2021, corrected publication 2021. This article is licensed under a Creative Commons Attribution 4.0 International License, which permits use, sharing, adaptation, distribution and reproduction in any medium or format, as long as you give appropriate credit to the original author(s) and the source, provide a link to the Creative Commons licence, and indicate if changes were made. The images or other third party material in this article are included in the article's Creative Commons licence, unless indicated otherwise in a credit line to the material. If material is not included in the article's Creative Commons licence and your intended use is not permitted by statutory regulation or exceeds the permitted use, you will need to obtain permission directly from the copyright holder. To view a copy of this licence, visit http://creativecommons.org/licenses/by/4.0/. The Creative Commons Public Domain Dedication waiver (http://creativeco mmons.org/publicdomain/zero/1.0/) applies to the data made available in this article, unless otherwise stated in a credit line to the data. 
church can be identified with certainty as the present $\mathrm{S}$. Pietro in Vincoli.

Accordingly, there is no reason to doubt that the present church as recorded in the Liber Pontificalis was founded by Pope Pelagius I (556-561) and completed by Pope John III (561-574) who consecrated the church, allegedly on May 1st 565. It was named "basilica apostolorum Philippi et Iacobi" [5]. A now lost building inscription over the main entrance to the church stated the same. A tradition which was recorded by the 15th Century chronicler Volaterrano claimed that the church was built to commemorate the victory of the Byzantine general Narses who defeated the Ostrogoths and regained control over the whole of Italy, including Rome, in the years 550-553. Such a late tradition might not be trustworthy in itself, but some historical facts point to the possibility that Narses was indeed connected to the building of the church. In 554 Narses held an official triumphal procession into Rome and in the following years he is known to have been involved in various restoration works in the city on behalf of the Byzantine emperor Justinian. It is not unlikely that he also supported the building of the church of the apostles Philip and Iacob/James since Pope Pelagius was known to be on very friendly terms with the Byzantine general. Narses seems to have lived in Rome during the period when the church was being built [9].

The theory of a strong Byzantine influence on the architecture of the church based on the involvement of Narses, suggesting a plan in the shape of a Greek cross $[2,10]$ has been rejected by several scholars $[8,11]$. However, this has now by and large been proven by archaeological means. The excavations in 1996 uncovered well preserved floors from the 6th Century which demonstrated that the plan of the church was from the outset shaped as a cross with apses at the ends of the east, north, and south wings, a so-called triconchos [9].

The main apse of the Roman church was decorated with mosaics including an inscription mentioning Pope John III and a dedication to the apostles Philip and James. The church underwent several repairs and rebuildings during the Middle Ages. In 885-891 the church, which was still described as the church of Philip and James, was thoroughly rebuilt by Pope Stephen VI. It received rich gifts and relics encompassing numerous saints that were found in Roman burial grounds. In the second half of the 8th Century it was for the first time called SS Apostoli, but the old name Philippi et Iacobi was still in use during the centuries thereafter. A dedication to all 12 apostles is as mentioned not known until the 10th Century. A new high altar ciborium designed by Lorenzo di Tebaldo was erected around 1162, incorporating the old reliquary/altar. An earthquake in 1348 damaged the church. Repair work was initiated decades later, during the time of Pope Martin V 1417-1431. The youngest coin found in the confessio with the relics of the saints dated to around 1400, which might be an indication that pilgrims had access to the shrine until about that time. However, during the rebuilding of the church in the beginning of the 15th Century the reliquary was changed; its opening in front was restricted to a narrow slot necessary for the passage of coins, perhaps because the altar was covered up or concealed in some way [5]. In 1463 the church was handed over to the Franciscan order. The church underwent several rebuildings during the 15th Century, and by the end of the Middle Ages it appeared as a basilica with three naves, yet still like in the 6th Century with three apses, one to the east and one at each end of the transept [12]. Although the old stone reliquary may not have been directly accessible anymore there remained in the church a strong awareness of continuity, especially concerning the position and construction of the various high altars and their direct connection downwards to the remains of the original patron saints.

Since the 16th Century the floor level of the whole church was raised significantly in order to protect the church against the very damaging floods that occurred repeatedly. Despite various repairs and rebuildings the old church was in such a bad condition, that around 1700 the decision was made to construct an almost totally new church designed by the architect Francesco Fontana. He made a careful recording of the old situation before he erected the new church inside the old church room. The inner southern walls of the old church room can now be accessed through a door in south side. The foundation stone was laid in 1702 and the church was consecrated in 1724. The altar designed by Nicola Corona-and changed in 1873-frames a huge painting by Domenico Muratori, depicting the double martyrdom of Philip and James [13]. Later, several restorations have taken place, especially in 1869-1879 under the architect Luca Caramini and the painter and sculpturer Luigi Fontana. They found the old stone reliquary for the saints and established a whole new crypt which was skilfully designed as an imitation of the catacombs [14]. In 1879 the relics were placed in a wooden box inside an imitation of an Early Christian sarcophagus, placed in a special room to the far east of the new crypt [8]. The marble from the original stone reliquary had already in 1873 been built into the foundation of the 18th Century high altar where it is still to be found [15].

\section{The Apostles}

The Santi Apostoli Church was originally dedicated to James and Philip, both of them traditionally considered to be apostles of Jesus. James (Iakob), however, the Lord's 
brother (Gal. 1:19), is not mentioned in any list of the Twelve, even though he seems to have had an important role in the Church of Jerusalem. The New Testament mentions him on eleven occasions (1 Cor 15:7; Gal 1:19; 2:9; 2:12; Acts 12:17; 15:13; 21:18; Mk 6:3; Mt 13:55; Jas 1:1; Jude 1). According to the Letter to the Galatians, he was "pillar of the Jerusalem Church" and as such participated in the conference (Acts 15:1-20; see also Gal 2:1-10) at Jerusalem, which intended to settle the question whether gentiles needed to be circumcised before becoming Christians [16]. His important role makes it even more remarkable that James is not included in any list of the apostles. One possible explanation comes from Paul's Letters. The fact that Paul considers him an apostle (Gal 1:19) $[17,18]$ and included him in the group of persons who had seen the risen Lord (1 Cor 15:7) may mean that the Lord's post-resurrection appearance precipitated James' conversion as it also happened with Paul [19]. The recognition of the apostleship of James by Paul implicitly emphasizes his own apostleship.

James's filial relationship with Jesus has been discussed extensively in the early Church, because of its bearing on the traditional doctrine of the perpetual virginity of Mary [20,21]. That James was a brother of Jesus has been explained in three ways. According to the Patristic and Greek Orthodox tradition (called the Epiphanian view), James and the other three brothers of Jesus named in the New Testament (Joses, Judas, and Simon according to Mk 6:3; Joseph, Simon, and Judas according to Mt 13:55) were sons of Joseph from a previous marriage. Ever since Church Father Jerome (Hieronymus), however, the Western Catholic tradition maintains that James was a cousin of Jesus (called the Hieronymian view [20]). Finally, the Helvidian view held by the modern Protestant tradition holds that James was a real son of Joseph and Mary.

In addition, later tradition tends to confuse James brother of Joses mentioned in Mark (15:40) with James the Lord's brother, and calls him St James "the Lesser", or "the Little" (Greek, o mikros). However, given his importance in the Church of Jerusalem, early Christians could hardly have called him "the Lesser" [21]. In fact, early Christian texts exclusively use the expressions "Lord's brother" or "the Just" (Hegesippus in Eusebius Hist. eccl. 2.23.4-18) in order to distinguish St James from other Jameses. The confusion between James the Lord's brother and James "the Lesser" was favoured by the Hieronymian view that considers St James not the brother but the cousin of Jesus. James and Joses were deemed to be sons of Mary (Mk 15:40; Mt 27:56), the wife of Clopas (who was then equated to Alphaeus) and sister of Jesus' mother (Jn 19:25). Eusebius reports that James was thrown from the pinnacle of the temple and was beaten to death with a club. According to Hegesippus, however, he was stoned, which seems to agree with the report of the historian Flavius Josephus [22] who affirms that the high priest Ananus accused James of transgressing the law and let him be stoned in ca. AD 70 .

James' relevance in the early Church can be seen in the number of writings attributed to him. To begin with, he is the alleged author of the "Epistle of James" in the New Testament. According to Origen, its author was "James" or "James the apostle" [23]. But Eusebius identified him already as the "Lord's brother", leader of the Church in Jerusalem [24]. However, it is Rufinus that first explicitly mentions "James, the brother of the Lord" as author of the Epistle (in his Latin translation of Origen's Commentary on Romans, 4.8). The Nag Hammadi collection of early Christian writings includes three different texts attributed to James, the Lord's brother, namely two apocalypses or 'revelatory texts' and an apocryphon, or 'Secret Book'. While the First Apocalypse of James (Nag Hammadi Codex V,3) predicts James' suffering, the Second Apocalypse of James (Nag Hammadi Codex V,4) narrates his stoning and death at the hands of the mob [16].

Quite differently, Philip (Philippos) was undisputedly one of the twelve apostles of Jesus and appears a total of sixteen times in the New Testament (Mt 10:3; Mk 3:18; Lc 6:14; Jn 1:43.44.45.46.48; 6:5.7; 12:21.22 [× 2]; 14:8.9; Acts 1:13). The Synoptic Gospels regularly mention him in the lists of disciples (Mt 10:3; Mk 3:18; Lk 6:14). It is, however, in the gospel of John where Philip obtains more importance. Jesus calls him to be one of the Twelve near Bethany beyond the Jordan River (Jn 1:43-44). Given that this was the place where John was baptizing (Jn 1:28), some believe that he might have been a disciple of John the Baptist [25]. John also tells that when tested by Jesus regarding how to feed the 5,000 in the wilderness, Philip considered only the expenses of the issue (Jn 6:5-7).

Original from Bethsaida, a predominantly Greek area (Jn 12:21), he was an intermediary between Jesus and Greeks who had come to worship at the Passover (Jn 12:20-26). During the Farewell Discourse, Philip asked Jesus for a vision of the Father, to which Jesus replied that he already had seen the Father in him (Jn 14:8-9). The Book of Acts, finally, counts him among the disciples who were waiting for the coming of the Holy Spirit in the Upper Room (Jn 1:13).

Later tradition placed his martyrdom in Hierapolis (Phrygia), but according to the oldest testimonies he was not a martyr (Heracleon on Lk 12:8-12) [26].

The story of his death in Hierapolis emanates from a confusion between Philip the Apostle and Philip the Evangelist, which we find already in Papias of Hierapolis (ca. AD 60-130). According to Papias, Philip the Apostle lived in Hierapolis with his daughters [24], something which seems to be confirmed by Polycrates [24]. He states 
that Philip the Apostle was buried at Hierapolis with two of his aged virgin daughters. However, according to the Book of Acts (Acts 21:8-9), it was not Philip the Apostle, but Philip the Evangelist who had four virgin daughters.

Be that as it may, this confusion is further echoed by the apocryphal Acts of Philip [27], which relate the miracles and death of the Apostle Philip and place his and Bartholomew's crucifixion upside down in the city of Hierapolis. The same tradition is echoed in the Martyrdom of Andrew, which mentions Samaria and Asia as his missionary regions. The apostle Philip appears in several of the Nag Hammadi texts. In the Letter of Peter to Philip [28] Peter asked Philip to re-join the apostles after he apparently had left them. Philip also appears in the Sophia of Jesus Christ [29] and the second Codex of Nag Hammadi includes a Gospel of Philip [30], the apostle whom the Gnostics considered receiver of a special revelation [31]. The text includes unknown sayings of Jesus and extracanonical stories about him.

\section{The Relics}

The most important relics preserved at the Basilica dei Santi Apostoli are fragments of the tibia and the foot of St Philip (including mummified soft tissue) and the femur of St James. The relics of the two apostles were contained in a quadrangular, $1.59 \times 1.59 \mathrm{~m}$, and $0.46 \mathrm{~m}$ high stone box (confessio) which was uncovered during archaeological investigations under the church in 1873 [8] and which was subsequently incorporated into the foundations of the 18th Century high altar. The reliquary originally stood in the centre of the semi-circular apse and was placed on a round platform raised about $1.40 \mathrm{~m}$ above the floor of the presbytery [32]. The lid of the reliquary consisted of two pieces of Docimium marble, a white marble from quarries near the Phrygian town of Docimium in Asia Minor. The marble lid had a profiled frame around a quadrangular depression marked with a large Greek cross in low relief. Beneath was a small opening into a deeper cavity which was divided into two by a vertical marble panel. Besides the well-preserved human bones, it contained a series of objects of wood, fabric, iron nails and pins, ten coins of various time periods the youngest one from around ca. 1400, and two small silver capsules containing fabric and balsam [33]. The coins as well as some of the other objects were probably deposited by pilgrims visiting the grave [5], while the bones are supposedly the original relics of Philip and James.
The origin of the relics of St Philip and St James should be searched for in the well-established custom of transferring, translating, saints' bones to shrines and churches that we see starting in the 4th Century (see "Discussion" section below). Due to the increasing veneration of saints, the translation of bones and relics from their graves to churches constructed in their honour intended to assure a continuous link between the patron saint and the ritual. As it was customary in the 6th Century, relics were placed in the apse in close vicinity of the altar since the proximity between altar and relics increased the connection between place, saint, and ritual. The Basilica dei Santi Apostoli is no exception to this traditional rule.

\section{Materials}

Two types of sample materials were obtained, one with the purpose of analysing the relics themselves, that is the bone-, mummy-, and associated materials. The aim of the second type of material was to provide information about the ancient architectural surroundings of the relics.

\section{Bone-, mummy-, and associated materials}

The relic samples were taken during a time when the church was refurbishing the showcases holding the relics. At the time of sampling, all materials were therefore kept in a storeroom at the friary. The fragmentary sample of the tibia of St Philip (KLR-11036/C90) and the fragmentary sample of the femur of St James (KLR-11037/C91) were taken by brother A. Stoia using a knife and transferring the material to clean, sterile medical test tubes. The rest of the samples were taken jointly by A. Stoia and K.L. Rasmussen using pre-cleaned stainless-steel utensils transferring the samples to sterile, clean medical test tubes (Fig. 1). The samples are listed in Table 1 (marked italics).

\section{Materials from the altar}

The restoration work enabled extracting building and other materials found in connection with what is suspected to be reminiscences of the original altar in the Basilica dei Santi Apostoli. Samples are listed in Table 1 (marked bolditalics). These samples were taken jointly by S. Schiavone, A. Stoia, and K.L. Rasmussen.

The ancient altar is situated inside and below the modern altar (Fig. 2). It was designed as two marble-walled boxes on top of each other, the big box above the small box. The small box has a side length of ca. 35 to $41 \mathrm{~cm}$

(See figure on next page.)

Fig. 1 Samples of bone- and mummy-material. a Tibia of St Philip KLR-11036/C90 (femur of St James KLR-11030/C81); b, c foot of St Philip KLR-12288/C18 and KLR-11029/C80; d Vaso-2 KLR-11032/C83; e Vaso-1 KLR-11033/C84; fVaso-6 St Philip KLR-11034/C85; g Vaso-B wood KLR-11035/ C86; $\mathbf{h}$ foot of St Philip; i fragmentary samples of femur of St James KLR-11037/C91; j, $\mathbf{k}$ femur of St James (mounted on a wooden peg and with a gilded ring) KLR-11251/C94 

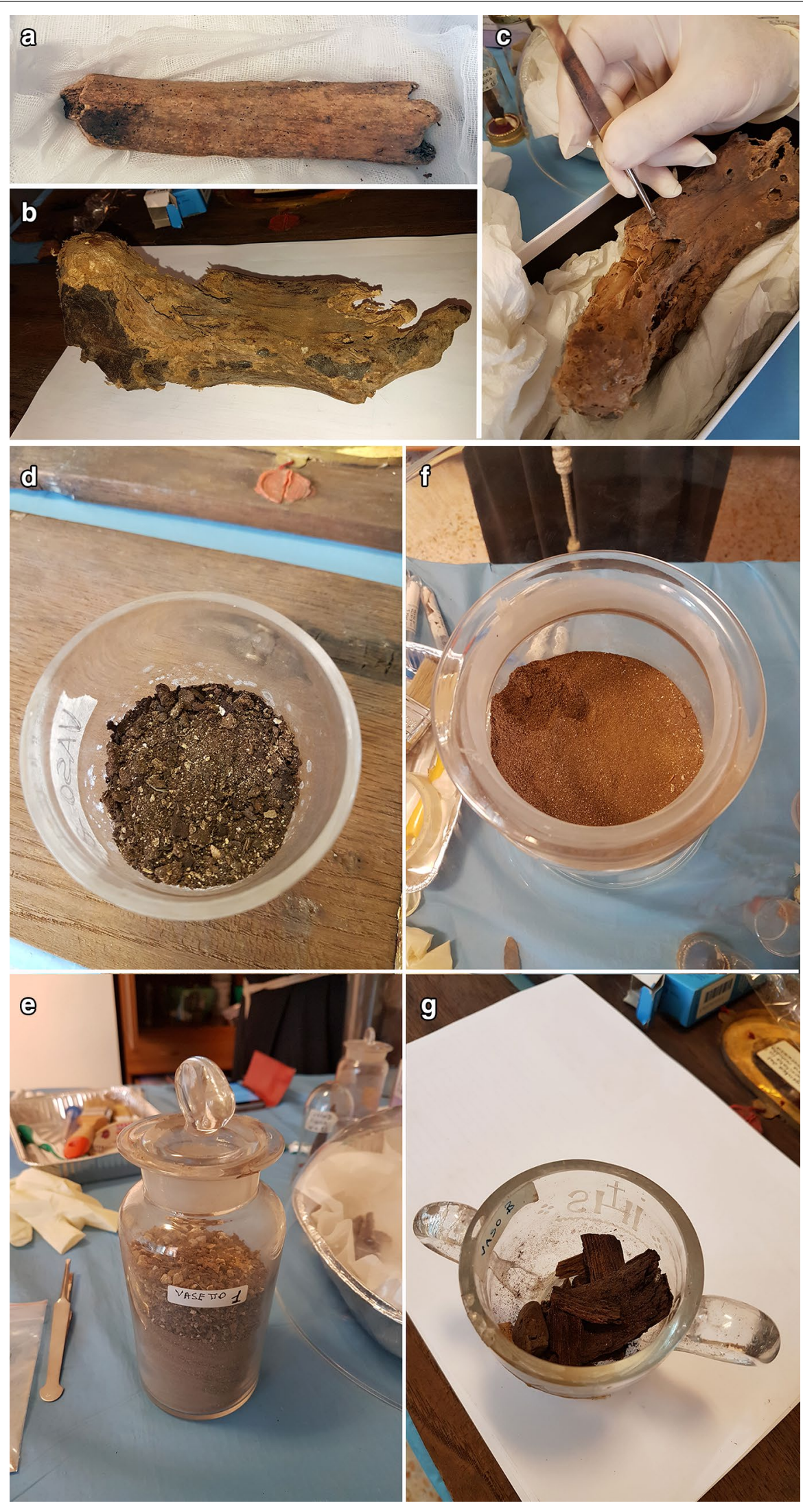


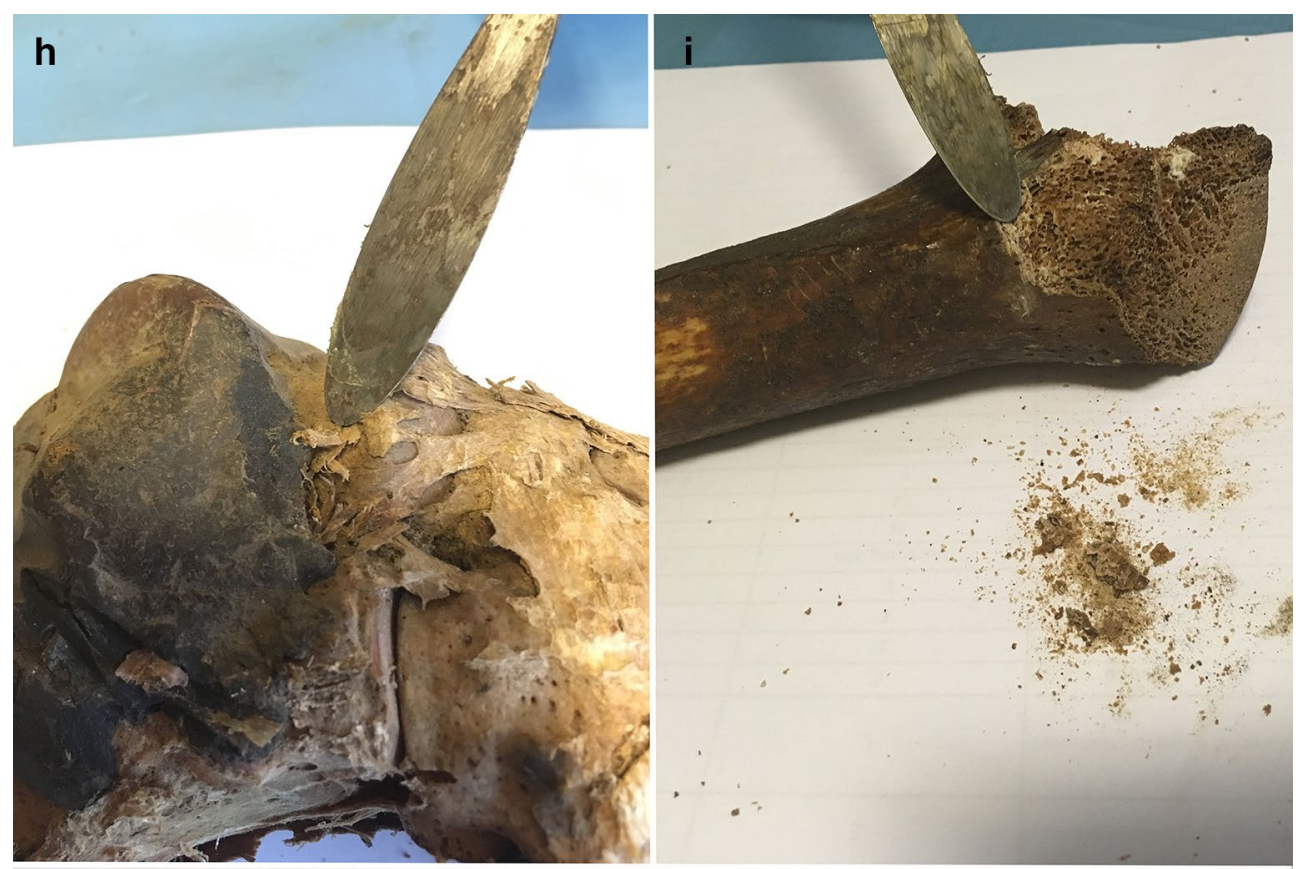

j

$\mathbf{k}$
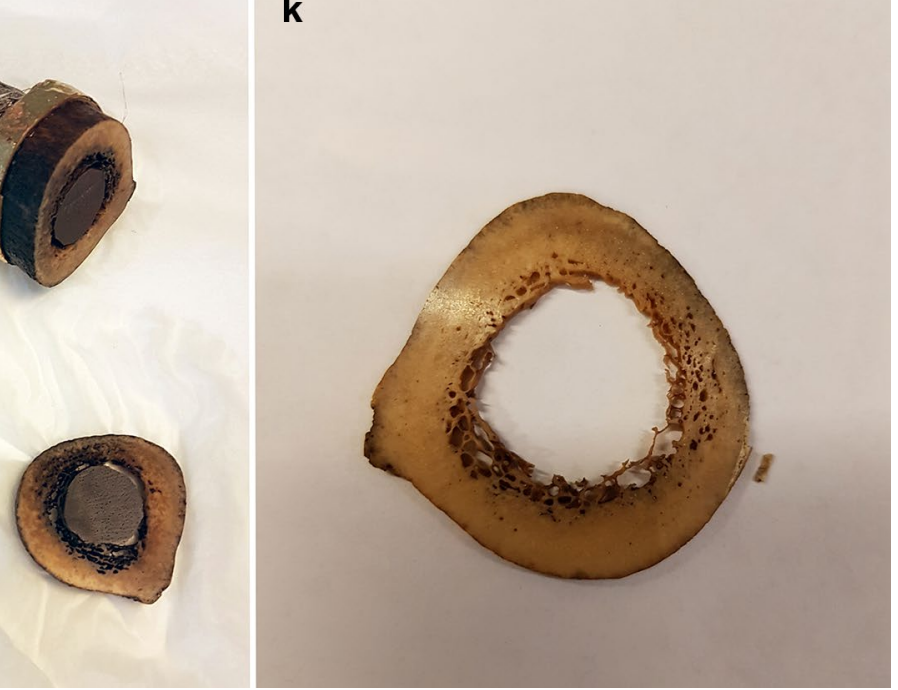

Fig. 1 continued

and a depth of 38 to $40 \mathrm{~cm}$ (Figs. 2c, 3a). The small box has three holes in the bottom: one original big hole (yellow arrow, diameter medium $4.5 \mathrm{~cm}$ ) and two smaller modern drill holes (blue arrows, diameters ca. $1.5 \mathrm{~cm}$ ), see Fig. 3c. At the surface outside the top level of the small box was in the south-west corner of the big box found what is here termed the ancient hole (sides ca. $15 \times 12 \mathrm{~cm}$, depth $30 \mathrm{~cm}$, red arrow in Fig. 3a, and detailed photo in Fig. 3b). Covering and adhering to the ancient hole was found a piece of ceramics (KLR-12381/ C101). All three holes in the bottom of the small box as well as the ancient hole must all lead to the crypt, which is situated several meters below. At the same level as the ancient hole, but in the south-east corner was found a canal leading diagonally from the south-east corner of the bottom of the big box to the south-east upper corner of the small box (see green arrows in Fig. 3a, d). The big box has side lengths of ca. $118 \times 125 \mathrm{~cm}$ (Figs. 3a, 4). The lower marble-slab of the big box has a circular hole in it (ca. $14 \mathrm{~cm}$ in diameter), and the underside was visibly affected by a fire, which at one time must have occurred in the small box (Fig. 4). 
Table 1 Samples analysed in the present work

\begin{tabular}{|c|c|c|c|c|}
\hline DSA No. & KLR No. & Material & Place/assignment & Analyses applied \\
\hline C18 & $K L R-12288$ & Embalming & St Philip & GC-MS, FIA-ESI-Q-TOF \\
\hline $\mathrm{C} 80$ & KLR-11029 & Skin upper foot & St Philip & ICP-MS, CV-AAS \\
\hline C81 & KLR-11030 & Bone dust & St James & ICP-MS, CV-AAS \\
\hline C82 & KLR-11031 & Textile & VasoA, INV84b & $C V-A A S, P y-G C-M S$ \\
\hline C83 & KLR-11032 & Textile & Vaso2, Inv55 & CV-AAS, GC-MS \\
\hline C84 & $K L R-11033$ & Textile & Vasol, Inv89 & $C V-A A S$ \\
\hline C85 & $K L R-11034$ & Ash & Vaso6, St Philip & ICP-MS, CV-AAS, GC-MS, FTIR, XRF, XRD \\
\hline C86 & KLR-11035 & Wood & VasoB & ICP-MS \\
\hline C90 & KLR-11036 & Fragm. Tibia & St Philip & ICP-MS \\
\hline C91 & KLR-11037 & Fragm. Femur & St James & ICP-MS, CV-AAS \\
\hline C94 & $K L R-11251 a$ & Femur CO & St James & ICP-MS, CV-AAS \\
\hline C94 & $K L R-11251 b$ & FemurTR & St James & ICP-MS, CV-AAS \\
\hline C94 & KLR-11251C & Femur OUTER & St James & ICP-MS, CV-AAS \\
\hline C94 & KLR-11251d & Femur & St James & GC-MS, C14 \\
\hline C93 & $K L R-12290$ & Encrustation & From canal & $\begin{array}{l}\text { GC-MS, HPLC-ESI-HRMS, XRD, XRF, } \\
\text { C14 }\end{array}$ \\
\hline C95 & $K L R-12382$ & Soot & From lower plate in big box & GC-MS, Raman \\
\hline C96 & $K L R-12383$ & Mortar/marble & Big hole in small box & $X R F, L A-I C P-M S$ \\
\hline C97 & $K L R-12384$ & Mortar/marble & Big hole in small box & GC-MS \\
\hline C98 & $K L R-12385$ & Mortar from canal & Canal & GC-MS, Environmental sample \\
\hline C100 & $K L R-12387$ & Mortar & Top/side of Ancient Hole & $X R F, L A-I C P-M S$ \\
\hline C101 & $K L R-12381$ & Ceramic shard & Ancient Hole above small box & TL-dating, XRF, LA-ICP-MS \\
\hline
\end{tabular}

Italics shading is bone and mummy materials, bolditalics shade indicates samples from the high altar and surroundings. DSA is Dei Santi Apostoli sample numbers; KLR-numbers are Odense laboratory numbers; in the 'Material' column is listed the type of material; in the 'Place/assignment' column is listed the place or to whom the sample is assigned; the last column lists the types of analyses conducted on the sample

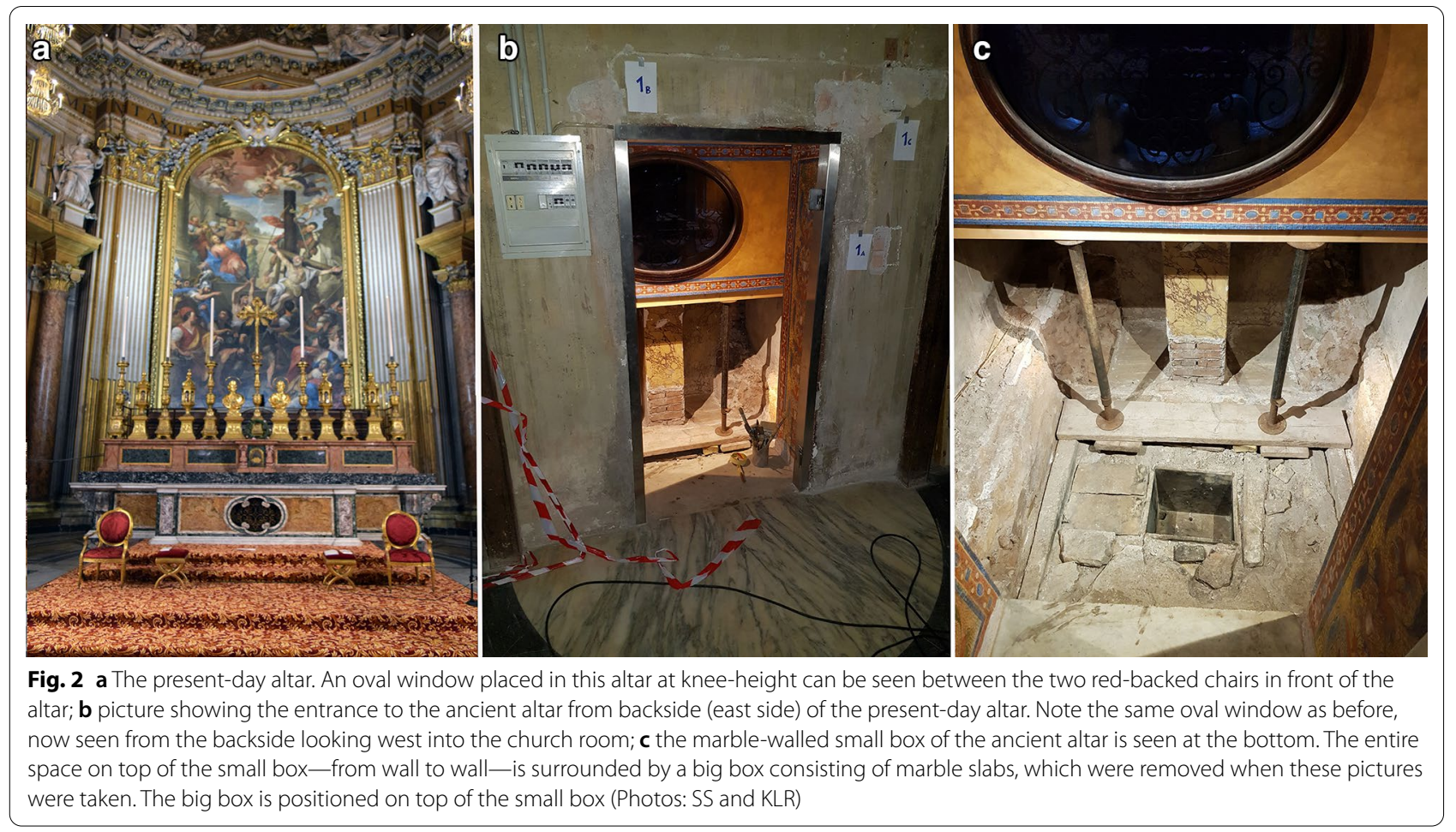



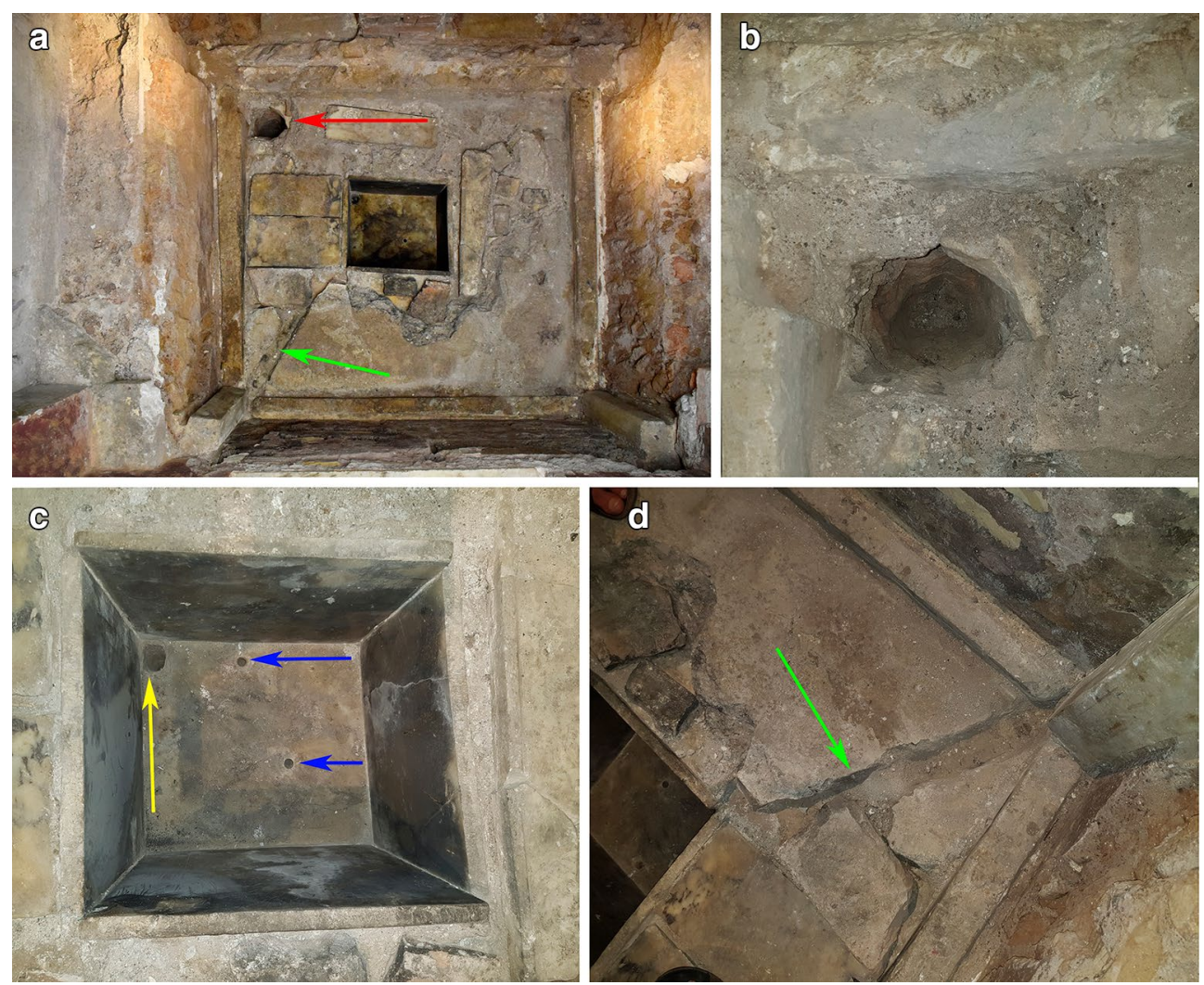

Fig. 3 a Top view of the big box. The green arrow points at a canal leading to the south-east corner of the small box. The encrustation KLR-12290/ C93 was found in the canal. Sample KLR-12385/C98 was taken from the wall material of the canal. The red arrow points to the position of an ancient hole. The yellow arrow points to the big hole inside the small box; $\mathbf{b}$ top-view of the ancient hole. In the top of the ancient hole a piece of ceramics (KLR-12381/C101) was found attached with mortar, but the age of the mortar has not been established. Samples on the side/top of the ancient hole was taken for the determination of the TL-background radiation (KLR-12387/C100); c top-view of the small box. The big hole in the upper left corner (south west corner, yellow arrow) is leading down to the crypt below. The two smaller holes are modern drillings, probably made in 1970's (blue arrows); $\mathbf{d}$ top-view of the canal (green arrow), which is running from the lower south-east corner of the big box to the upper south-east corner of the small box (Photos: SS and KLR)

\section{Methods}

Inductively Coupled Plasma Mass Spectrometry (ICP-MS)

The major and trace elements $\mathrm{Ca}, \mathrm{Mn}, \mathrm{Fe}, \mathrm{Cu}, \mathrm{Sr}, \mathrm{Ba}$, and $\mathrm{Pb}$ were measured by ICP-MS (Inductively Coupled Plasma Mass Spectrometry). Each sample weighing between 1 and $40 \mathrm{mg}$ was dissolved in a mixture of $4 \mathrm{~mL} 69 \% \mathrm{HNO}_{3}$ and $2 \mathrm{~mL} \mathrm{30 \%} \mathrm{H}_{2} \mathrm{O}_{2}$, both of ICP-MSgrade (TraceSELECT ${ }^{\circledR}$ Fluka). The digestion took place in new, sealed disposable polystyrene containers, which were left on a shaking table for $24 \mathrm{~h}$ at room temperature $\left(\right.$ ca. $\left.20^{\circ} \mathrm{C}\right)$. The surplus hydrogen peroxide, which was not consumed during the digestion, was driven off by adding $0.67 \mathrm{~mL} 30 \%$ ICP-MS-grade $\mathrm{HCl}$ (PlasmaPURE Plus ${ }^{\circledR}$ SCP Science). The samples were then diluted to $10 \mathrm{~mL}$ with Milli-Q water and filtered through $0.45 \mu \mathrm{m}$ PVDF Q-Max disposable filters. The samples were divided in halves, and one half was further diluted and used for ICP-MS, while the other half was used for
CV-AAS (see below). The solutions were stored at $+4{ }^{\circ} \mathrm{C}$ until the analyses were performed the next day. The analyses were carried out on a Bruker ICP-MS 820, equipped with a frequency-matching RF generator and a Collision Reaction Interface (CRI), operating with either helium or hydrogen as skimmer gas. The basic parameters were as follows: radiofrequency power $1.40 \mathrm{~kW}$, plasma gas flow $15.50 \mathrm{~L} \mathrm{~min}^{-1}$; auxiliary gas flow $1.65 \mathrm{~L} \mathrm{~min}^{-1}$; sheath gas flow $0.12 \mathrm{~L} \mathrm{~min}^{-1}$; nebulizer gas flow $1.00 \mathrm{~L} \mathrm{~min}^{-1}$. The $\mathrm{CRI}$ reaction system was activated for $\mathrm{Fe}$ and $\mathrm{Cu}$ because of interferences with polyatomic species produced by a combination of isotopes coming from the argon plasma, reagents, or the matrix. A mixture of ${ }^{45} \mathrm{Sc},{ }^{89} \mathrm{Y}$, and ${ }^{159} \mathrm{~Tb}$ was used as internal standard added to all analyses. The following isotopes were measured without skimmer gas: ${ }^{44} \mathrm{Ca},{ }^{55} \mathrm{Mn},{ }^{88} \mathrm{Sr},{ }^{137} \mathrm{Ba}$, and ${ }^{208} \mathrm{~Pb} .{ }^{56} \mathrm{Fe}$ was measured with hydrogen as skimmer gas. ${ }^{63} \mathrm{Cu}$ was analysed with helium 

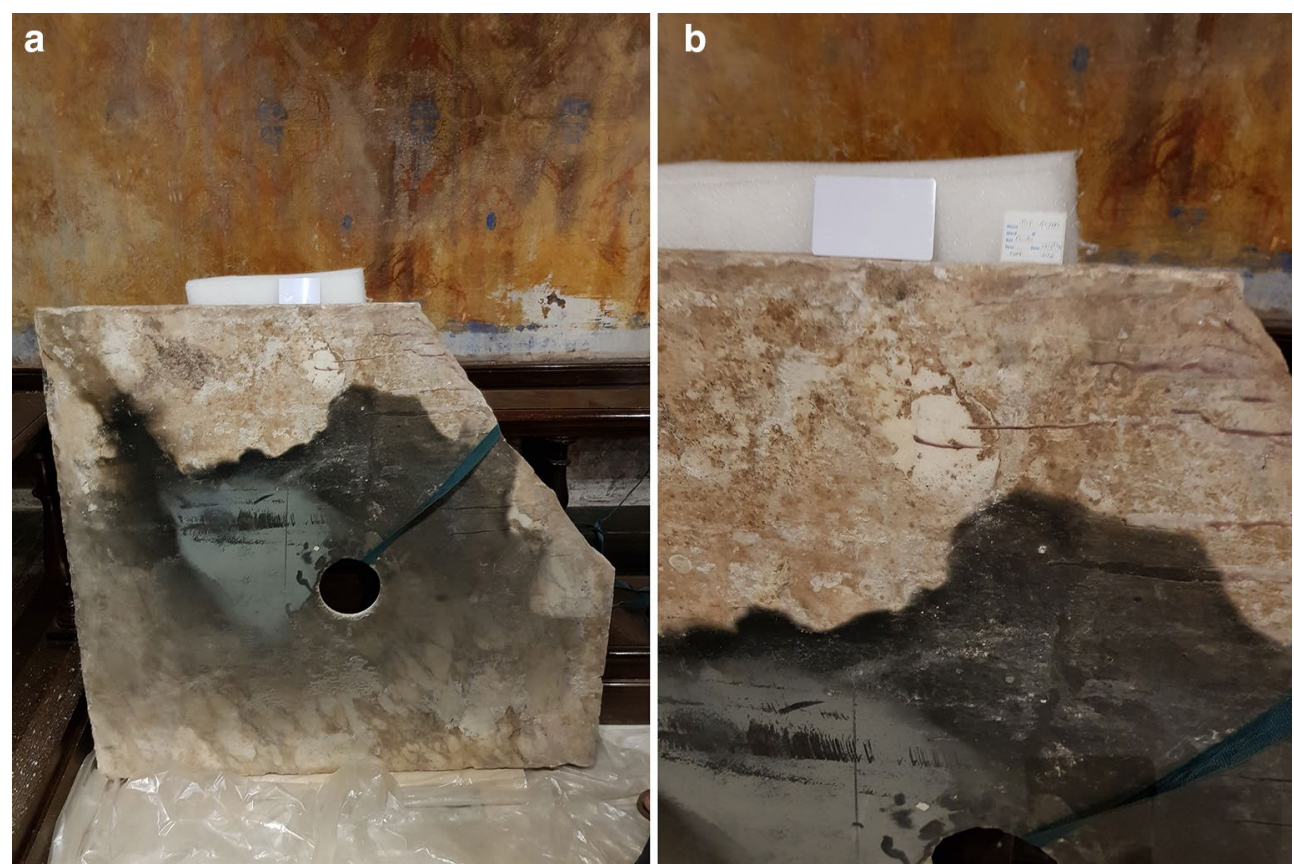

Fig. 4 a The bottom marble plate removed from the big box seen from the underside, i.e. the side turning down towards the small box below, where there seems to have been a fire at some time. Side length ca $115 \times 115 \mathrm{~cm}$. b Detail of the same. Blank white card for scale on top: length $8.5 \mathrm{~cm}$. The scorched area has been sampled for Raman analysis (KLR-12382/C95). (Photos: KLR)

as skimmer gas. The dwell time on each peak was $30 \mathrm{~ms}$. There were made 5 replicate analyses of each sample and each replicate consisted of 30 mass scans. Multi-element calibration standards were prepared in $1 \% \mathrm{HNO}_{3}$ at 6 different concentrations $\left(0,1,10,20,100\right.$, and $\left.200 \mu \mathrm{g} \mathrm{L}^{-1}\right)$, but for each element only 3 standards were selected to fit the concentration range found in the sample. For $\mathrm{Ca}$ three standards of 100, 200, and $250 \mu \mathrm{g} \mathrm{g}^{-1}$ were used. Each day an in-house standard sample manufactured from a homogenized medieval bone was analysed along with the samples in order to monitor the overall performance. Together with the samples was also analysed an international standard, NIST SRM-1486, a modern bone sample. For the modern samples more $\mathrm{H}_{2} \mathrm{O}_{2}$ had to be added in order to cope with its higher collagen content. The Limits Of Quantifications (LOQ's) were: Al: $3.63 \mu \mathrm{g} \mathrm{g}^{-1}$; Ca: $40.7 \mu \mathrm{g} \mathrm{g}^{-1}$; Mn: $0.51 \mu \mathrm{g} \mathrm{g}^{-1}$; Fe: $13.5 \mu \mathrm{g} \mathrm{g}^{-1}$; $\mathrm{Cu}: 2.56 \mu \mathrm{g} \mathrm{g}^{-1}$; As: $1.67 \mu \mathrm{g} \mathrm{g}^{-1}$; $\mathrm{Sr}$ : $0.72 \mu \mathrm{g} \mathrm{g}^{-1}$; Ba: $0.49 \mu \mathrm{g} \mathrm{g}^{-1}$; and Pb: $0.49 \mu \mathrm{g} \mathrm{g}^{-1}$.

\section{Cold Vapour Atomic Absorption Spectroscopy (CV-AAS)}

The $\mathrm{Hg}$ concentration was measured by cold vapour atomic absorption spectroscopy on a dedicated mercury analyser, a Flow Injection Mercury System (FIMS-400) by PerkinElmer. This system featured a better detection limit for $\mathrm{Hg}$ than the ICP-MS, which tends to be overloaded with $\mathrm{Hg}$ from the continuous daily analyses of medieval human bones, some of which show elevated $\mathrm{Hg}$ levels. Two hours prior to analysis $1 \mathrm{~mL}$ of concentrated $\mathrm{KMnO}_{4}$ was added to $5 \mathrm{~mL}$ of sample to maintain the $\mathrm{Hg}$ in the solution in ionic form. Next, the sample was diluted to $20 \mathrm{~mL}$. In the reaction chamber of the FIMS400 the $\mathrm{Hg}$ was released as vapour by adding $\mathrm{NaBH}_{4}$. The analyser was operated in the continuous flow mode. An in-house human bone standard was dissolved daily together with the samples and included in the daily runs in order to monitor any drift in the systems [34, 35]. The overall uncertainties, i.e. the uncertainties including reproducibility and dilution, was estimated to be ca. $\pm 3.0 \%$ (RSD at $1 \sigma$ ) for Hg. The LOD (Limit of detection) was ca. $1.5 \mathrm{ng} \mathrm{g}^{-1}$ for a human bone sample of ca. $20 \mathrm{mg}$, and the LOQ (Limit of quantification) was calculated to $8.72 \mathrm{ng} \mathrm{g}^{-1}$ based on daily measurements of the in-house standard sample over half a year.

\section{Gas Chromatography Mass Spectrometry (GC-MS)}

For the GC-MS analysis the samples were subjected to saponification, extraction, and derivatization with BSTFA prior the analysis. The samples were subjected to microwave assisted extraction (200 W power) using an Ethos One oven system (Milestone, USA) with $300 \mu \mathrm{L}$ of potassium hydroxide in ethanol $10 \mathrm{wt} \%$ at $80{ }^{\circ} \mathrm{C}$ for $60 \mathrm{~min}$ [36]. 
After hydrolysis, the neutral compounds were extracted with $n$-hexane; the residual solution was acidified $(\mathrm{pH}=2)$ with hydrochloric acid $(6 \mathrm{M})$ and then the acidic compounds were extracted with diethyl ether $(400 \mu \mathrm{L}$, three times). The two extracts were combined in order to analyse them in a single chromatographic run, evaporated to dryness under nitrogen stream and subjected to derivatization with $20 \mu \mathrm{L}$ of N,O-bistrimethylsilyltrifluoroacetamide (BSTFA) with $1 \%$ trimethylchlorosilane, $150 \mu \mathrm{L}$ of iso-octane and $5 \mu \mathrm{L}$ of tridecanoic acid (internal standard for derivatization) solution at $60{ }^{\circ} \mathrm{C}$ for $30 \mathrm{~min} .5 \mu \mathrm{L}$ of hexadecane solution (internal standard for injection) were added just before injection.

The GC-MS system consisted of an Agilent Technologies (USA) $6890 \mathrm{~N}$ Gas Chromatograph with a split/splitless injection port coupled with an Agilent Technologies 5973 mass selective single quadrupole mass spectrometer. The GC-MS conditions were adapted from BlancoZubiaguirre et al. [36]. Perfluorotributylamine (PFTBA) was used for mass spectrometer tuning. MSD ChemStation (Agilent Technologies) software was used for data analysis and peak assignment was based on the comparison with libraries of mass spectra (NIST 8.0) and an in-house library of trimethylsilyl derivatives of selected molecular markers of lipid and resinous materials.

\section{Pyrolysis Gas Chromatography Mass Spectrometry (Py-GC- MS)}

The analyses were performed using a multi-shot pyrolyzer EGA-PY-3030D (Frontier Lab, Japan) coupled with a $6890 \mathrm{~N}$ gas chromatography system with a split/ splitless injection port and combined with a 5973-mass selective single quadrupole mass spectrometer (Agilent Technologies).

The samples (about $100 \mu \mathrm{g}$ ) were placed in stainlesssteel cups and directly analyzed without further sample pre-treatment [37]. The pyrolysis conditions were optimized as follows: pyrolysis chamber temperature $550{ }^{\circ} \mathrm{C}$, interface $280^{\circ} \mathrm{C}$. The $\mathrm{GC}$ injector temperature was $280{ }^{\circ} \mathrm{C}$. The GC injection was operating in split mode and the best analytical results were obtained with a split ratio of 1:10. The chromatographic separation of pyrolysis products was performed on a fused silica capillary column HP-5MS (5\% diphenyl-95\% dimethyl-polysiloxane, $30 \mathrm{~m} \times 0.25 \mathrm{~mm}$ inner diameter, $0.25 \mu \mathrm{m}$ film thickness, J\&W Scientific, Agilent Technologies), preceded by $2 \mathrm{~m}$ of deactivated fused silica pre-column with internal diameter of $0.32 \mathrm{~mm}$. The chromatographic conditions for the analysis were: $36{ }^{\circ} \mathrm{C}$ for $10 \mathrm{~min}, 10{ }^{\circ} \mathrm{C} \mathrm{min}{ }^{-1}$ to $280{ }^{\circ} \mathrm{C}$, $300{ }^{\circ} \mathrm{C}$ for $2 \mathrm{~min}, 15^{\circ} \mathrm{C} \mathrm{m^{-1 }}$ to $300{ }^{\circ} \mathrm{C}$. The carrier gas was helium (purity 99.9995\%) with a gas flow set in constant flow mode at $1.2 \mathrm{~mL} \mathrm{~min}^{-1}$. The MS parameters were as follows: electron impact ionization (EI, $70 \mathrm{eV}$ ) in positive mode; ion source temperature $230{ }^{\circ} \mathrm{C}$; scan range $50-700 \mathrm{~m} / \mathrm{z}$; interface temperature $280{ }^{\circ} \mathrm{C}$. Perfluorotributylamine (PFTBA) was used for mass spectrometer tuning. MSD ChemStation (Agilent Technologies) software was used for data analysis and peak assignment was based on a comparison with literature mass spectra, standard compounds previously analysed in the same conditions, and libraries of mass spectra (NIST 8.0).

\section{X-ray Fluorescence analysis (XRF)}

The X-ray fluorescence analysis was performed using a benchtop ED-XRF Rigaku QC+Quantez spectrometer equipped with a Silicate Drift Detector (SDD), 6-position automatic sample changer and an He purge with a flow of $0.2 \mathrm{~L} \mathrm{~min}^{-1}$. The spectrometer was operated at a voltage of $50 \mathrm{kV}$ and at a current of $169 \mu \mathrm{A}$. Automatic primary filters were used to improve the detection of mid- $Z$ and high- $Z$ elements. The procedure for sample preparation included: (1) calcination of the samples to $950{ }^{\circ} \mathrm{C}$ for $6 \mathrm{~h}$; (2) manually crushing the samples in an agate mortar and sieve the powder to keep the fraction below $300 \mu \mathrm{m}$; and (3) weighing $400 \mathrm{mg} \pm 5 \mathrm{mg}$ of sample powder to prepare the aliquot for the XRF analysis. The quantification was done using the SRMs NIST 2711a Montana soil II, and 98b Plastic Clay measured in the exact same conditions and the same sample weight.

\section{Micro X-ray fluorescence analysis ( $\mu$-XRF)}

$\mu$-XRF analyses were carried out using an ARTAX800 manufactured by Bruker-Nano. The beam size was $60 \mu \mathrm{m}$. A high tension of $50 \mathrm{kV}$ and a current of $600 \mu \mathrm{A}$ were used. Absolute calibration of the concentrations was done using the DCCR-method (Direct Calibration from Count Rates) provided by the Bruker software using the standard reference material NIST-2711. The results can only be considered semi-quantitative because of differences between the NIST-2711 standard material and the matrix of the samples.

\section{Powder X-ray diffraction (XRD)}

The analysis was performed using a PANalytical X'Pert PRO MPD system (PW3050/60) with $\mathrm{Cu} \mathrm{K \alpha}$ radiation as the source $(\lambda=1.54 \AA)$ and a PIXcel3D detector. The $\mathrm{X}$-ray generator was set to an acceleration voltage of $45 \mathrm{kV}$ and a filament emission current to $40 \mathrm{~mA}$. The divergence slit was fixed at $0.43^{\circ}$. The capillary sample holder was mounted in an HTK 1200 N Capillary Extension (Anton Paar) with a ceramic anti-scatter shield. The sample was scanned while spinning between $5^{\circ}(2 \theta)$ and $90^{\circ}(2 \theta)$ using a step size of $0.013^{\circ}(2 \theta)$ with a counting time of 260 s. Data were collected using X'Pert Data Collector. The qualitative analysis was performed using Highscore Plus software and Crystal Impact Match 
software. The ICDD PDF-2 database and the updated COD database have been used to interpret the results. The semi-quantitative results have been measured using the Reference Intensity Ratio method (RIR).

\section{Raman spectroscopy}

Raman spectra were obtained with a micro-Raman Invia instrument (Renishaw) equipped with a Leica microscope with a $50 \times$ objective. A diffraction grating with 1800 grooves $\mathrm{mm}^{-1}$ and a CCD detector was used.

\section{Flow injection and high-pressure liquid chromatography analysis high resolution mass spectrometry analysis (FIA-HRMS, HPLC-ESI-HRMS)}

The sample was submitted to extraction using a Milestone microwaves Ethos One system with $300 \mu \mathrm{L}$ of a chloroform:hexane (3:2) solution for $25 \mathrm{~min}$ at $80^{\circ} \mathrm{C}$ with a irradiation power of $600 \mathrm{~W}$. The extracts were dried, diluted in the elution mixture and filtered on $0.45 \mu \mathrm{m}$ PTFE filters (Grace Davison Discovery Sciences, USA) before the injection [36, 38].

FIA-ESI-Q-ToF flow injection analysis (FIA) was carried out using a 1200 Infinity HPLC coupled to a Jet Stream ESI interface with a Quadrupole-Time-of-Flight tandem mass spectrometer 6530 Infinity Q-ToF (Agilent Technologies. The eluents were methanol:water (85:15) and iso-propanol (50:50); the flow rate was $0.2 \mathrm{~mL} \mathrm{~min}^{-1}$ and the injection volume was $1 \mu \mathrm{L}$. The ESI operating conditions were adopted from La Nasa et al. [39]. The data were collected both by full scan and by target MS-

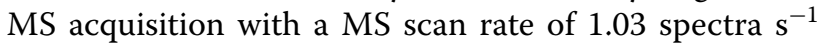
and MS-MS scan rate of 1.05 spectra $^{-1}$. The mass axis was calibrated daily using the Agilent tuning mix HP0321 (Agilent Technologies, US) prepared in acetonitrile.

For the HPLC-ESI-HRMS analyses the samples were extracted using the same microwave approach reported above. The separation was performed on an Agilent Poroshell 120 EC-C18 column $(3.0 \mathrm{~mm} \times 50 \mathrm{~mm}$, $2.7 \mu \mathrm{m})$ with a Zorbax eclipse plus $\mathrm{C}-18$ guard column $(4.6 \mathrm{~mm} \times 12.5 \mathrm{~mm}, 5 \mu \mathrm{m})$; The eluents were methanol:water (85:15) and iso-propanol. The data were collected both by full scan and by target MS-MS acquisition with a MS scan rate of 1.03 spectra $\mathrm{s}^{-1}$ and MS-MS

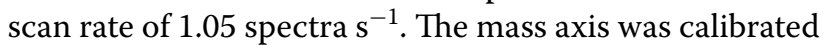
daily using the Agilent tuning mix HP0321 (Agilent Technologies, US) prepared in acetonitrile.

The full chromatographic and ESI operating conditions were adopted from references [40-42].

\section{Fourier transform infrared spectroscopy (FTIR)}

The Fourier transform infrared spectroscopy was performed using an Agilent Technology, Cary 630 with an Attenuated Total Reflection (ATR) diamond crystal accessory. Spectra were collected from 32 co-added scans in the spectral range of $4000-650 \mathrm{~cm}^{-1}$ with a resolution of $8 \mathrm{~cm}^{-1}$. The background was measured with 32 scans and subtracted from the spectra. The instrument was controlled through a MicroLab software and data were processed with the Spectragryph software (v.1.2.14; [43]).

\section{Radiocarbon dating}

Samples of bone and oil were dated by radiocarbon: bone in Oxford (UK, laboratory code OxA), and oil in Groningen (the Netherlands, laboratory code GrM). It was decided that only the well-preserved femoral bone of St James, KLR-11251/C94, was suited for an attempt of radiocarbon dating. Circa one quarter of a full ca. $1 \mathrm{~mm}$ thick cross section was selected and mechanically decontaminated at the periosteum and endosteum, leaving only pristine cortical tissue. A small fraction of the sample was then analysed in Pisa for the presence of contaminants (see below). Next, two samples were dated in Oxford. For the first sample (OxA-38266) "bulk collagen" was prepared from a $750 \mathrm{mg}$ cortical bone sample, pre-treated following the routine procedure comprising Soxhlet solvent wash with acetone, methanol and chloroform, followed by decalcification in acid, a base wash, re-acidification, gelatinisation and ultrafiltration, as described by Brock et al. [44]. For a second sample (OxA39529), the single amino acid radiocarbon dating method was applied. This method involves separation of the underivatised amino acids using preparative HPLC (High Performance Liquid Chromatography) after hydrolysis of the bone collagen. Using this method, the amino acid hydroxyproline was isolated [45].

Following pre-treatment, the isolated compound (datable fraction) was combusted in a $\mathrm{CHN}$-analyser. This was coupled to an IRMS (Isotope Ratio Mass Spectrometer) for measuring the stable isotope ratios $\delta^{13} \mathrm{C}$ and $\delta^{15} \mathrm{~N}$. The analyser also provided $\mathrm{CO}_{2}$ for the ${ }^{14} \mathrm{C}$ analysis. This $\mathrm{CO}_{2}$ was transformed into graphite by reduction with $\mathrm{H}_{2}$-gas. The ${ }^{14} \mathrm{C}$-content in the graphite was measured by Accelerator Mass Spectrometry (AMS). The Oxford AMS is a Tandetron operating at $2.5 \mathrm{MV}$. For more details, see Bronk Ramsey [46].

The oil extracted in Pisa from the encrustation sample KLR-12290/C93 was dated in Groningen. Groningen employs a modern so-called Micadas AMS-system, operating at $200 \mathrm{kV}$ [47]. The machine can analyse ${ }^{14} \mathrm{C}$ in graphite and in $\mathrm{CO}_{2}$ gas; here graphite was used. The oil was directly (as a fluid) injected into a Sn capsule. This $\mathrm{Sn}$ capsule with the sample was combusted in a CHNanalyser, producing $\mathrm{CO}_{2}$ [48]. The analyser was coupled to an IRMS yielding $\delta^{13} \mathrm{C}$ and $\delta^{15} \mathrm{~N}$ isotope ratios. Subsequently, the ${ }^{14} \mathrm{C}$-content in the graphite was measured by Accelerator Mass Spectrometry (AMS). This is essentially 
the same AMS method as utilized in Oxford (see above). All measurement batches (both laboratories, all methods) contain reference samples (standards, backgrounds, and control samples).

The ${ }^{14} \mathrm{C}$-dates are reported by convention in $\mathrm{BP}$, i.e. measured relative to oxalic acid standard, corrected for isotopic fractionation using the stable isotope ratio ${ }^{13} \mathrm{C} /{ }^{12} \mathrm{C}$ to $\delta^{13} \mathrm{C}=-25 \%$, and using a half-life value of 5568 years [49]. The ${ }^{14} \mathrm{C}$ dates were calibrated into calendar ages. This was done using the OxCal code [46] and the new high-resolution calibration curve IntCal20 [50].

The stable isotope ratios are expressed in delta $(\delta)$ values, which are defined as the deviation (expressed in per mil) of the rare to abundant isotope ratio from that of a reference material:

$$
\begin{aligned}
& { }^{13} \delta=\frac{\left({ }^{13} C /{ }^{12} C\right)_{\text {sample }}}{\left({ }^{13} C /{ }^{12} C\right)_{\text {reference }}}-1(\times 1000 \%) \text { and } \\
& { }^{15} \delta=\frac{\left({ }^{15} N /{ }^{14} N\right)_{\text {sample }}}{\left({ }^{15} N /{ }^{14} N\right)_{\text {reference }}}-1(\times 1000 \%)
\end{aligned}
$$

For carbon, the reference material is belemnite carbonate (V-PDB); for nitrogen, the reference is ambient air (see [51]). The typical analytical error is $0.1 \%$ and $0.2 \%$ for $\delta^{13} \mathrm{C}$ and $\delta^{15} \mathrm{~N}$, respectively.

\section{Thermoluminescence dating (TL)}

The ceramic shard found at the entrance of the ancient hole (KLR-12381/C101) was dated by thermoluminescence (TL). Two samples of the surroundings of the ancient hole (KLR-12383/C96 and KLR-12387/C100) were taken in order to obtain an estimate of the $\mathrm{U}$, Th, and $\mathrm{K}$ concentrations of the surroundings of the shard. A fraction of sample KLR-12381/C101 was crushed and sieved in a dark room and $40 \mathrm{mg}$ of the fraction between 100 and $300 \mu \mathrm{m}$ was taken out for TL-measurement.

The TL measurements were performed on a DA-12 TL-reader from Risø National Laboratory with the 100$300 \mu \mathrm{m}$ granulometric fraction of sieved grains using the Single Aliquot Regeneration method adapted from Hong et al. [52], taking the average of four subsamples. To calculate the age, it is needed to determine the doses received from the environment. These are assumed to originate from three sources: (1) the internal source which consists of the four radioactive isotopes present in the sample: ${ }^{40} \mathrm{~K},{ }^{235} \mathrm{U},{ }^{238} \mathrm{U}$, and ${ }^{232} \mathrm{Th}$; (2) the external source from the same four isotopes in the surroundings; and (3) the cosmic flux.

Another part of the sample KLR-12381/C101, as well as the samples KLR-12383/C101 and KLR-12387/C100 were cut on a low velocity saw, embedded in Epoxy resin, and polished to a finish of $1 \mu \mathrm{m}$ diamond paste. The radioactive isotopes from the sample and the surroundings were measured using LA-ICP-MS (for $\mathrm{Si}$, Th, and U) and XRF (for $\mathrm{Si}$ and $\mathrm{K}$ ), see below. The cosmic flux was assumed to be $180 \pm 30 \mu \mathrm{Gy} \mathrm{year}^{-1}$. The calculation was performed using the "Luminescence" package on $R$ software [53]. The procedure required adjustment from factors affecting the dose rates: (1) the self-shielding was calculated with a measured average density of $1.8 \pm 0.3 \mathrm{~g} \mathrm{~cm}^{-3}$, (2) the grain diameter after sieving was assumed to be $200 \pm 100 \mu \mathrm{m}$, (3) the alpha efficiency was assumed to be $0.08 \pm 0.02$ according to [54], and (4) the water content, which was determined to be $1 \mathrm{wt} \%$. No HF etching was applied; thus, the alpha particle dose was included in the annual dose rate calculation [55]. These parameters were computed and processed through the AGE software [56] to provide the dose rates and the TL-age.

\section{Laser ablation inductively coupled plasma mass spectrometry (LA-ICP-MS)}

Uranium and Th were determined by Laser Ablation Inductively Coupled Plasma Mass Spectrometry (LAICP-MS). The ablation was performed with a CETAC LXS-213 G2 equipped with a NdYAG laser operating at the fifth harmonic at a wavelength of $213 \mathrm{~nm}$. A $25 \mu \mathrm{m}$ circular aperture was used. The shot frequency was $20 \mathrm{~Hz}$. A line scan was performed with a scan speed of $20 \mu \mathrm{m} \mathrm{s}^{-1}$ and was ca $300 \mathrm{~s}$ long following a $10 \mathrm{~s}$ gas blank. The helium flow was $600 \mathrm{~mL} \mathrm{~m}^{-1}$. The laser operations were controlled by the DigiLaz G2 software provided by CETAC. The inductively coupled plasma mass spectrometry (ICP-MS) analyses were carried out using a Bruker Aurora M90 equipped with a frequency matching RF-generator. The basic parameters were as follows: radiofrequency power $1.30 \mathrm{~kW}$; plasma argon gas flow rate $16.50 \mathrm{~L} \mathrm{~min}^{-1}$; auxiliary gas flow rate $1.65 \mathrm{~L} \mathrm{~min}^{-1}$; sheath gas flow rate $0.18 \mathrm{~L} \mathrm{~min}{ }^{-1}$. The following isotopes were measured without skimmer gas: ${ }^{29} \mathrm{Si},{ }^{232} \mathrm{Th}$, and ${ }^{238} \mathrm{U}$. No interference corrections were applied to the selected isotopes. The analysis mode used was peak hopping with 3 points per peak, and the dwell time was $10 \mathrm{~ms}$ on ${ }^{29} \mathrm{Si}$ and $100 \mathrm{~ms}$ on ${ }^{232} \mathrm{Th}$ and ${ }^{238} \mathrm{U}$. The quantification was performed with a method similar to Gratuze [57]. Three standard reference materials were run before and after each batch: NIST610 and NIST612 glass standards and NIST2711 Montana soil II in pressed pellets. The concentration of $U$ and Th were calculated by comparison of the $\mathrm{U} / \mathrm{Si}$ and $\mathrm{Th} / \mathrm{Si}$ experimental ratios to the $\mathrm{U} / \mathrm{Si}$ and $\mathrm{Th} / \mathrm{Si}$ in an in-house standard ceramic material sample. A relative error of ca. $10 \%$ is assumed from these measurements, mainly due to the mineral heterogeneity of the sample. 
Table 2 Measurements of $\mathrm{Hg}$ acquired through CV-AAS analysis

\begin{tabular}{|c|c|c|c|c|c|c|}
\hline KLR No. & DSA & Context & Material & $\begin{array}{l}\mathrm{Hg} \\
\mathrm{ng} / \mathrm{g}\end{array}$ & $\begin{array}{l}\mathrm{Hg} \\
\mathrm{SD}\end{array}$ & $\begin{array}{l}\mathrm{Hg} \\
\mathrm{RSD} \%\end{array}$ \\
\hline KLR-11029 & $\mathrm{C} 80$ & Philip & Foot tissue (over side, dark) & 309801 & 14279 & 4.6 \\
\hline KLR-11034 & C85 & Vaso 6 & 'Ash' & 11228 & 215 & 1.9 \\
\hline KLR-11036 & C90 & Philip & Tibia (bone fragment) & 968 & 47.6 & 4.9 \\
\hline KLR-11030 & $\mathrm{C} 81$ & James & Femur (bone dust) & 36203 & 1471 & 4.1 \\
\hline KLR-11037 & C91 & James & Femur (bone dust) & 1423 & 44.1 & 3.1 \\
\hline KLR-11251a & C94 & James & Bone, Cortical & 42.2 & 2.50 & 5.9 \\
\hline KLR-11251b & C94 & James & Bone, Trabecular & 4465 & 120 & 2.7 \\
\hline KLR-11251C & C94 & James & Bone, Surface & 20870 & 154 & 0.7 \\
\hline KLR-11035 & C86 & Vaso B & Wood & 5531 & 141 & 2.5 \\
\hline KLR-11031 & C82 & Vaso A & Textile & 25670 & 1048 & 4.1 \\
\hline KLR-11032 & $\mathrm{C} 83$ & Vaso 2 & Textile & 68668 & 955 & 1.4 \\
\hline KLR-11033 & C84 & Vaso 1 & Textile & 15254 & 465 & 3.0 \\
\hline
\end{tabular}

$\mathrm{SD}$ is one standard deviation. RSD is the relative standard deviation given in percent of the concentration value

\section{Results}

Inorganic analyses of the bone and mummy materials

The bone and mummy samples were subjected to $\mathrm{CV}$ AAS analysis to establish the concentration of $\mathrm{Hg}$. The results are listed in Table 2.

The cortical tissue samples of the long bones from St James and St Philip as well as Vaso 6 and Vaso B material have been analysed for other trace elements as well. The concentrations of the trace elements are listed in Table 3.

\section{Analyses of the encrustation sample}

The samples KLR-12290/C93 (encrustation) and KLR12384/C97 (ancient hole) were characterized by similar compositions: the chromatograms were mainly characterized by the presence of fatty acids, with palmitic, stearic, eicosanoic, erucic, docosanoic and tetracosanoic acids as most abundant (Fig. 5). The presence of these fatty acids with a specifically high amount of erucic acid, together with long chain hydroxy acids, suggests the presence of rapeseed oil [58]. The occurrence of phytosterols further confirm the presence of a vegetable oil. To confirm the botanical origin of the oil even further, sample KLR-12290/C93 was analysed by HPLC-ESI-HRMS (Fig. 5). The lipid profile consisted of monoglycerides, hydroxy fatty acids, and traces of erucic acid compatible only with a highly hydrolysed rapeseed oil.

This oil was a cheap lipid material that in antiquity was used mainly as fuel for lamps. Interestingly, the presence of erucic acid suggests that the oil detected in the samples is not modern since modern Brassica oils do not contain this fatty acid: erucic acid is toxic for humans and animals alike and during the years (from ca. 1960) the plants were gradually selected in order to obtain oils with lower amounts of this acid [59].
The GC-MS analyses also showed the presence of traces of lupenone and $\beta$-amyrin, triterpenes common in different aromatic oleo-resins, such as frankincense, probably added as fragrance to the oil [60].

The encrustation sample KLR-12290/C93 has also been analysed by $\mu$-XRF and XRD. The $\mu-X R F$ spectrum is shown in Fig. 6 and the semi-quantitative results calculated using the Bruker software is listed in Table 4.

The X-ray diffraction pattern is shown in Fig. 7. The socalled reference intensity ratio (RIR) calculation, where concentrations are estimated by comparing the ratios of the intensity of the diffraction lines in the experimental pattern to that of a known compound, showed that $96 \%$ of the sample consisted of $\mathrm{CaCO}_{3}, 3 \% \mathrm{BaCO}_{3}$, and $1 \%$ $\mathrm{ZnS}$. These results are in relatively good accordance with the $\mu$-XRF results, which shows a Ca concentration of ca. 30 wt \%, corresponding to $75 \%$ calcite. The discordance is probably caused by absolute calibration of the $\mu$-XRF, which is inherently difficult for major elements. Zink is also seen in the $\mu$-XRF spectrum (0.85 wt \%), which is in fine accordance with the $1 \%$ calculated from the XRD pattern. Barium is detected in the $\mu$-XRF spectrum and quantified to $0.25 \mathrm{wt} \%$. This low Ba concentration and the less than a perfect match with the $\mathrm{CaCO}_{3}$ concentration is likely caused by inhomogeneities in the sample. It should also be noted that the XRD is reflecting the average in ca $500 \mathrm{mg}$ of crushed sample, whereas the $\mu$-XRF with a beam size of $60 \mu \mathrm{m}$ reflects the composition in less than a mg of material. It is a viable interpretation that the inorganic part of the encrustation is likely chalkstone precipitated from running water, which has been led though a $\mathrm{Zn}$ - and $\mathrm{Pb}$-rich metallic pipe. The encrustation had a high porosity and a good ability to absorb and maintain the rapeseed oil described above. 


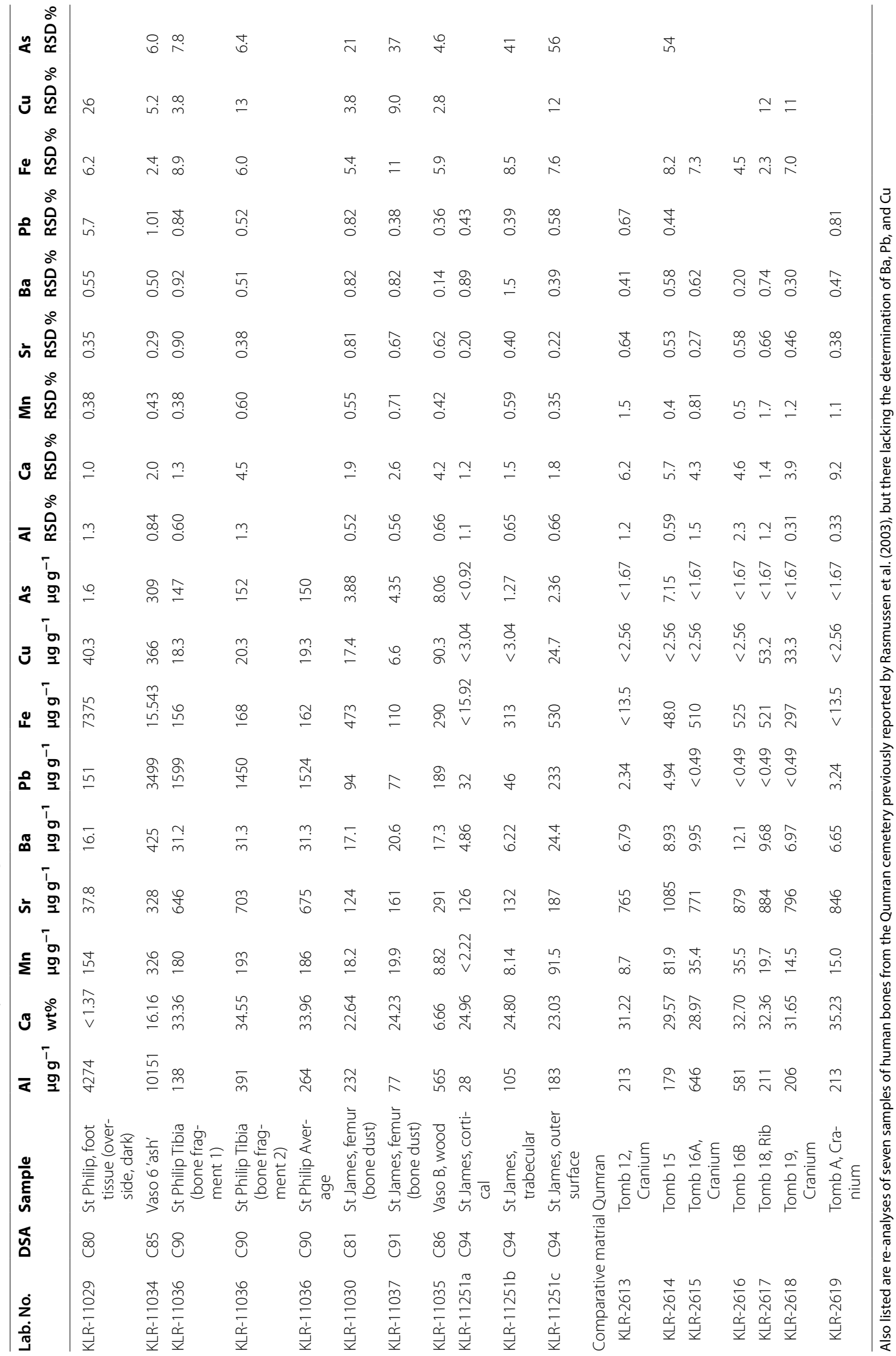




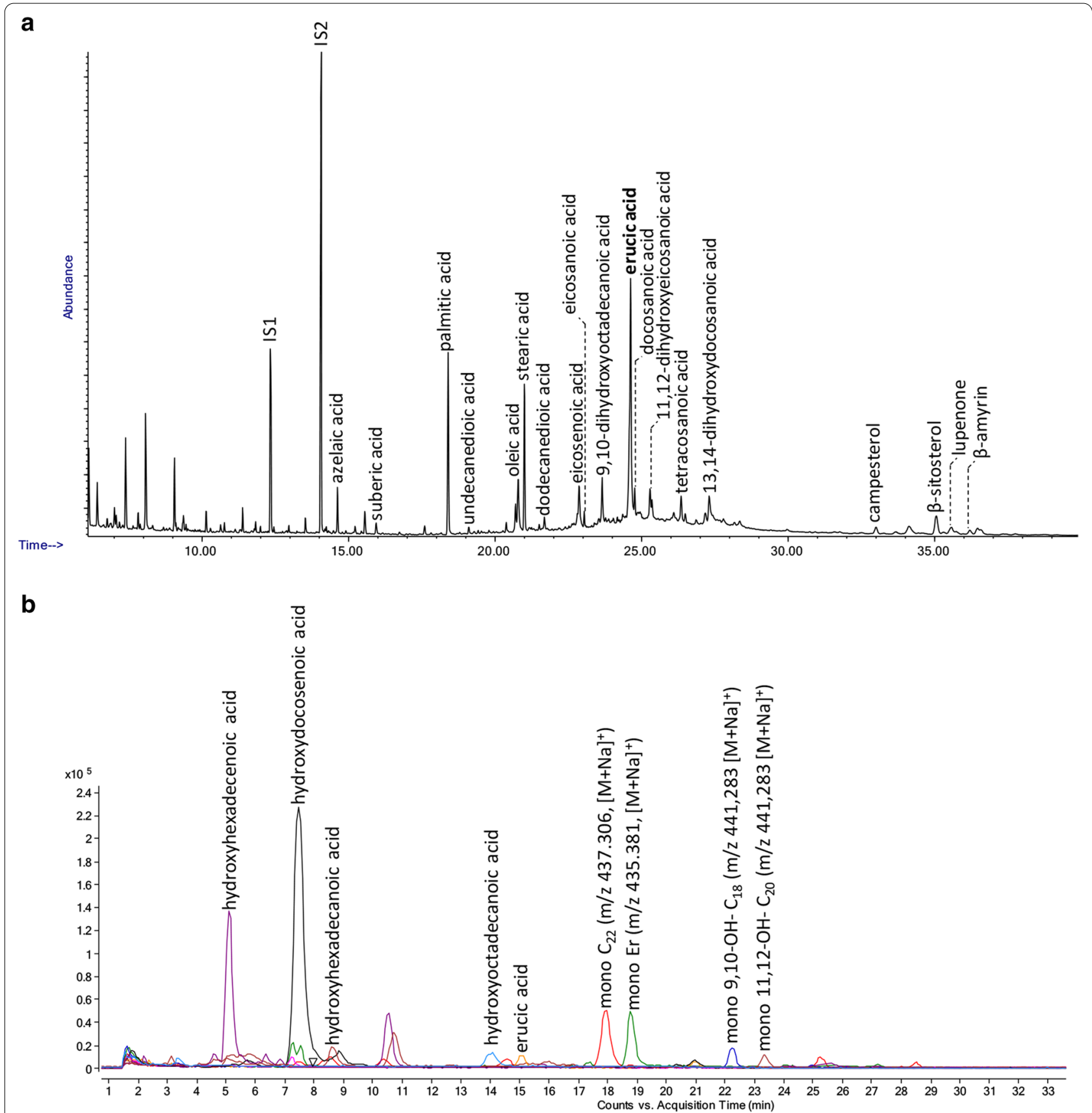

Fig. 5 a GC-MS chromatograms obtained after saponification, extraction, and derivatization for sample KLR-12290/C93 encrustation (above); and $\mathbf{b}$ HPLC-ESI-HRMS extracted ion chromatograms of KLR-12290/C93 (below)

\section{Analyses of the soot}

Before the GC-MS analysis a sample of $3.0 \mathrm{mg}$ was subjected to saponification. The chromatogram of sample KLR-12382/C95 (soot) was characterized by the presence of low amounts of fatty acids, next to the limit of detection. The presence of palmitic, stearic and erucic acids in low amounts suggests the presence of traces of rapeseed oil. The Raman spectroscopy analysis showed the presence of the emission bands characteristic of carbon black, probably deriving from a combustion (Fig. 8).

The chromatogram obtained for sample KLR-12385/ C98 (environmental sample from canal) was characterized by absence of markers characteristic of a lipid 


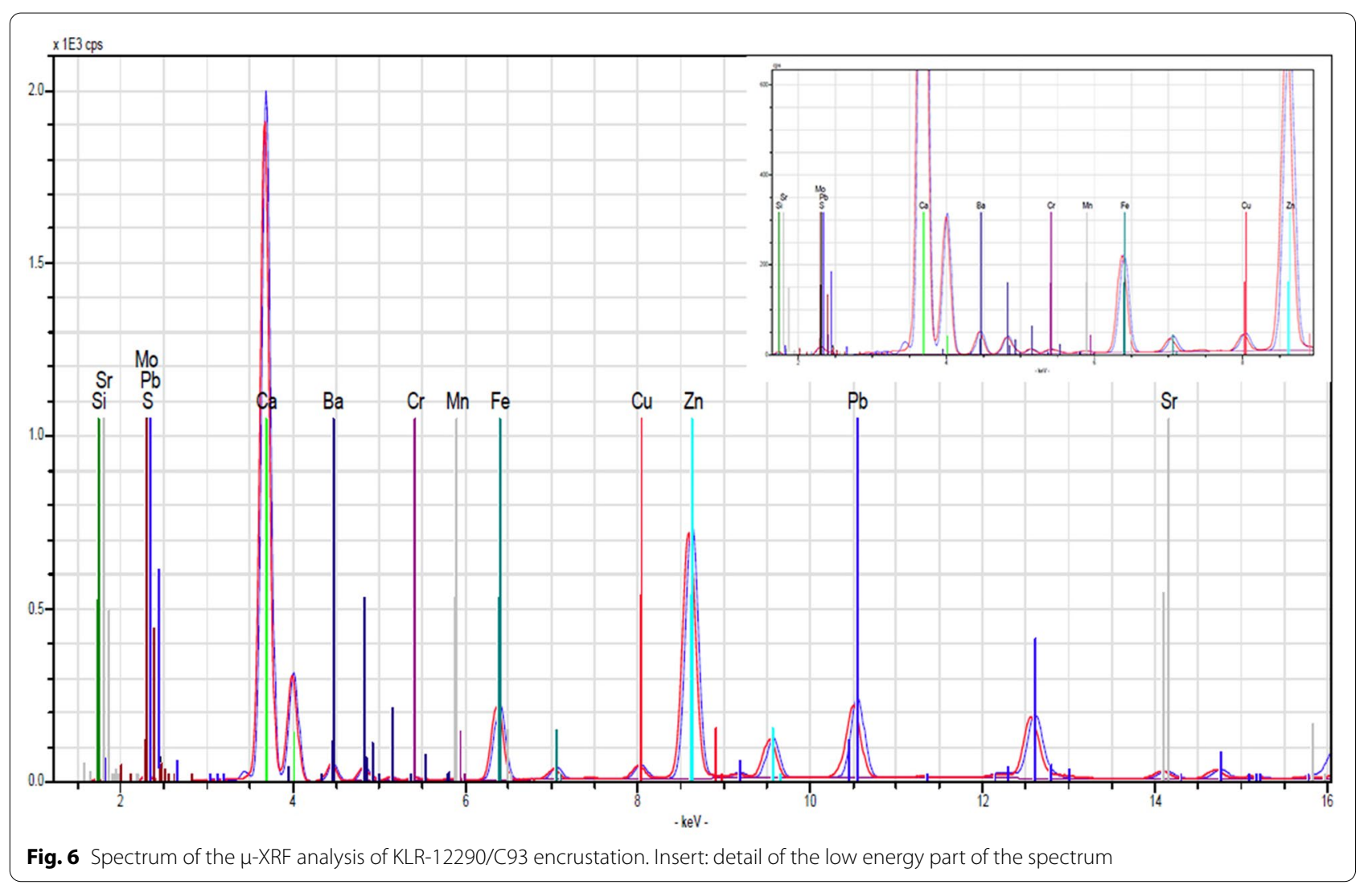

Table 4 Semi-quantitative results of the $\mu$-XRF analysis of sample KLR-12290/C93 encrustation. The NIST2711 standard material was used for absolute calibration using the Bruker software

\begin{tabular}{ll}
\hline Element & $\begin{array}{l}\text { Conc. } \\
\text { wt\% }\end{array}$ \\
\hline $\mathrm{Si}$ & 5.18 \\
$\mathrm{Ca}$ & 29.8 \\
$\mathrm{Fe}$ & 0.55 \\
$\mathrm{Cu}$ & 0.05 \\
$\mathrm{Zn}$ & 0.85 \\
$\mathrm{Sr}$ & 0.024 \\
$\mathrm{Ba}$ & 0.25 \\
$\mathrm{~Pb}$ & 0.46 \\
\hline
\end{tabular}

material, except for palmitic and stearic acids that are also common environmental contaminants.

\section{Analyses of sample KLR-12288/C18 embalming material} In the sample of embalming KLR-12288/C18 the fatty acid profile was characterized by the presence of fatty and dicarboxylic acids, vegetable sterols, all markers characteristic of a vegetable oil (Fig. 9). In addition, the analyses showed the presence of several hydroxy acids associated with skin fat of the mummy. The GC-MS analyses highlight also the presence of traces of erucic acid, associated with rapeseed oil: even if this fatty acid is a specific marker of this type of lipid material, the presence of the mummy hydroxy fatty acids (similar to those characteristic of aged rapeseed oil) does not allow a straightforward identification to be performed. The GC-MS analyses showed the presence of pimaric, dehydroabietic and abietic acids, associated with pine resin. Furthermore, the GC-MS analyses showed the presence of phenol, cinnamic, and vanillin derivatives which can be associated with the soluble portion of the wood fragments present in the samples. Finally, traces of 15-hydroxyhexadecanoic acid, associated with beeswax were detected.

The FIA-HRMS analyses highlighted the presence of esters characteristic of beeswax, and traces of acylglycerols containing erucic acid (mono: $\mathrm{m} / \mathrm{z} 435.381$ $[\mathrm{M}+\mathrm{Na}]^{+}$; di: $\mathrm{m} / \mathrm{z} 755.650[\mathrm{M}+\mathrm{Na}]^{+}$; tri: $\mathrm{m} / \mathrm{z}$ 1075,960 $[\mathrm{M}+\mathrm{Na}]^{+}$) characteristic of rapeseed oil, and therefore confirming the presence of both materials. 


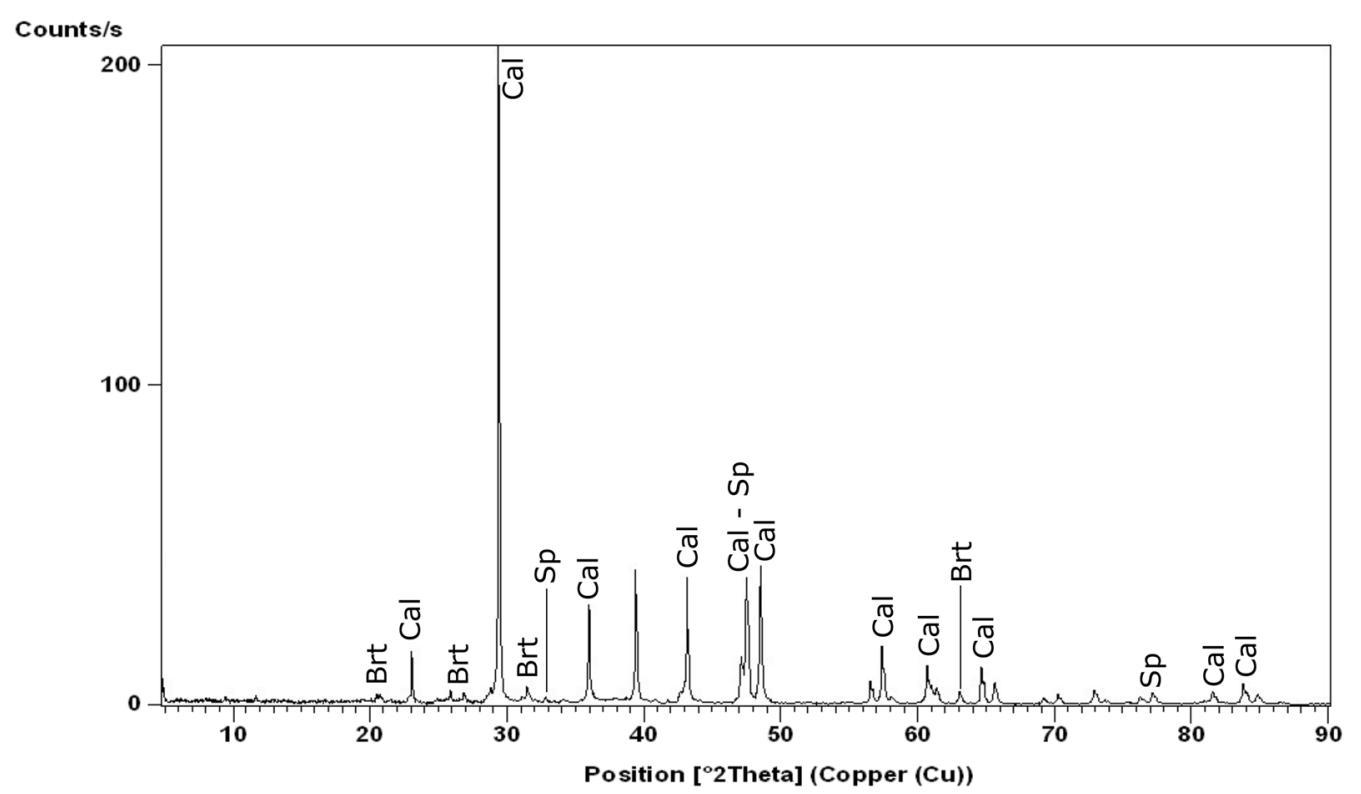

Fig. 7 XRD pattern of the sample KLR-12290/C93 encrustation. The following abbreviations are used: Cal, Calcite; Sp, Sphalerite; Brt, Barite. RIR calculations revealed a composition of $96 \%$ calcite; $3 \%$ barite; and $1 \%$ sphalerite

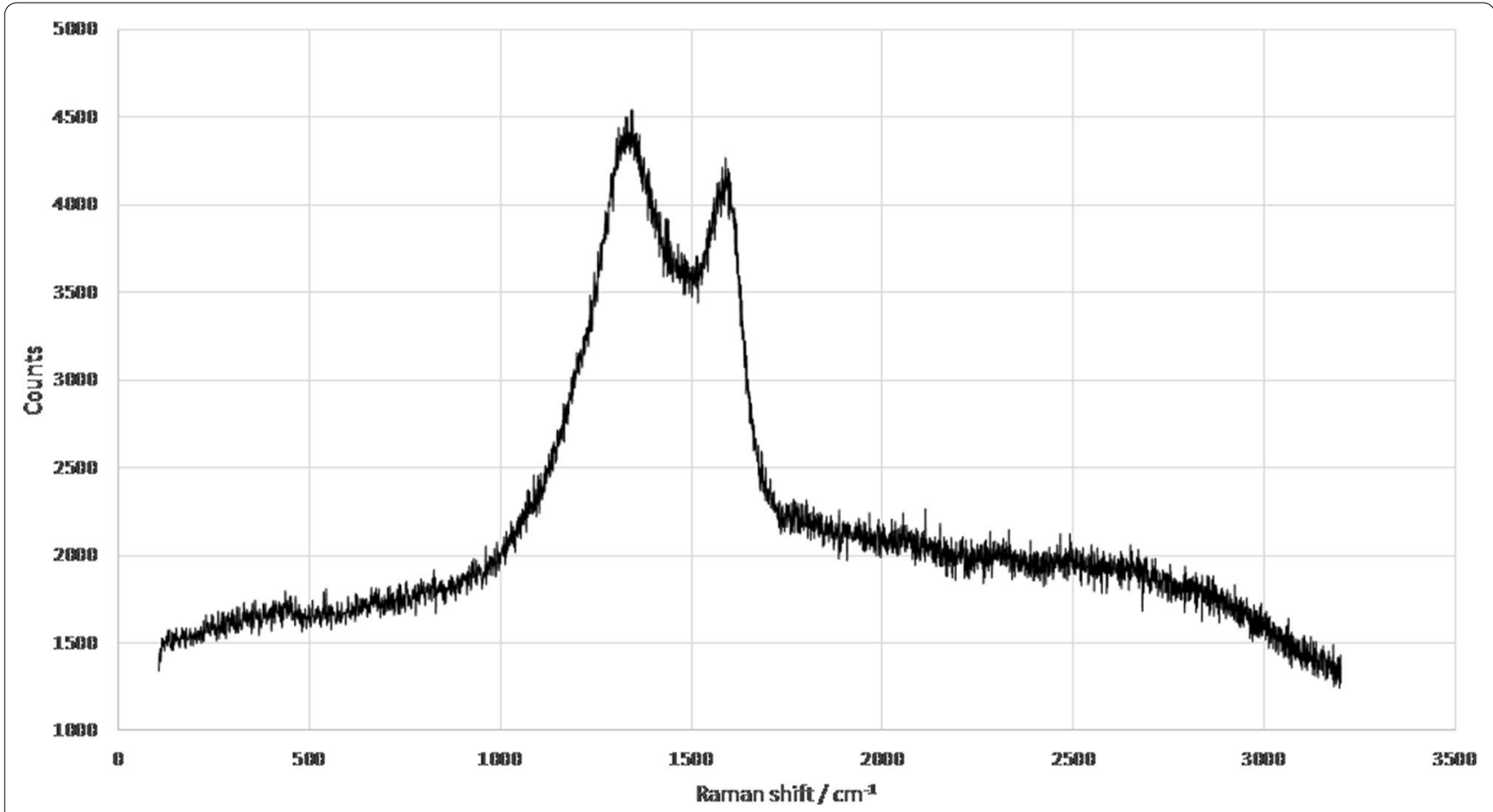

Fig. 8 Raman spectrum of the soot sample KLR-12382/C95. Courtesy of National Research Council of Italy, Pisa, Italy

Py-GC-MS analysis of the Vaso A textile sample KLR-11031/C82 The Py-GC-MS profile of the fiber was characterized by the presence of pyrrole derivatives, phenols, and diketopiperazines (Fig. 10). The pyrolytic profile is consistent with that of silk.
GC-MS analyses of the textile sample KLR-11032/C83

The GC-MS chromatogram obtained for textile sample KLR-11032/C83 is characterized by the presence of molecular markers characteristic of beeswax (15-hydroxyhexacosanoic acid, long chain fatty acids and alcohols). 


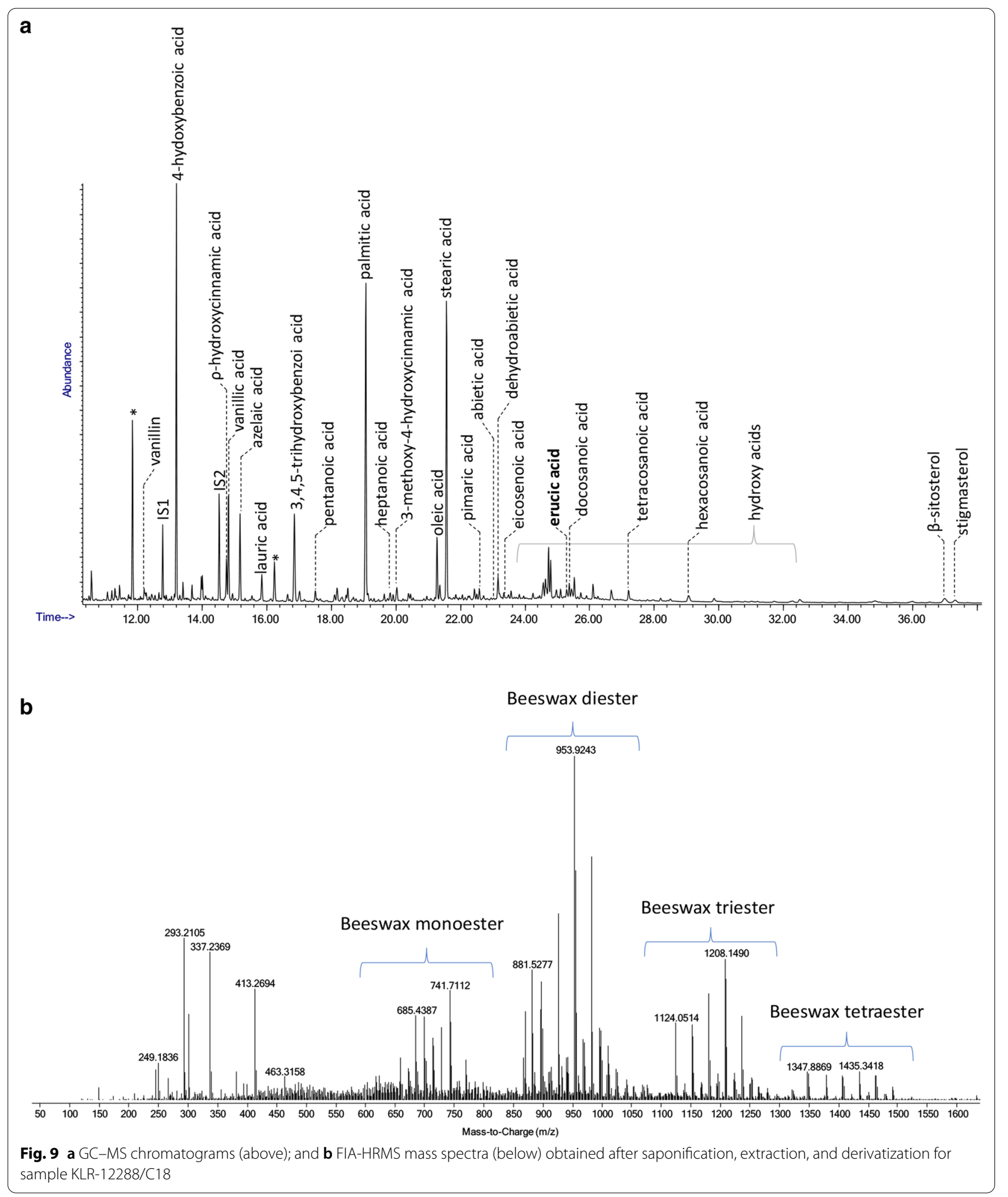


Rasmussen et al. Herit Sci (2021) 9:14

Page 19 of 30
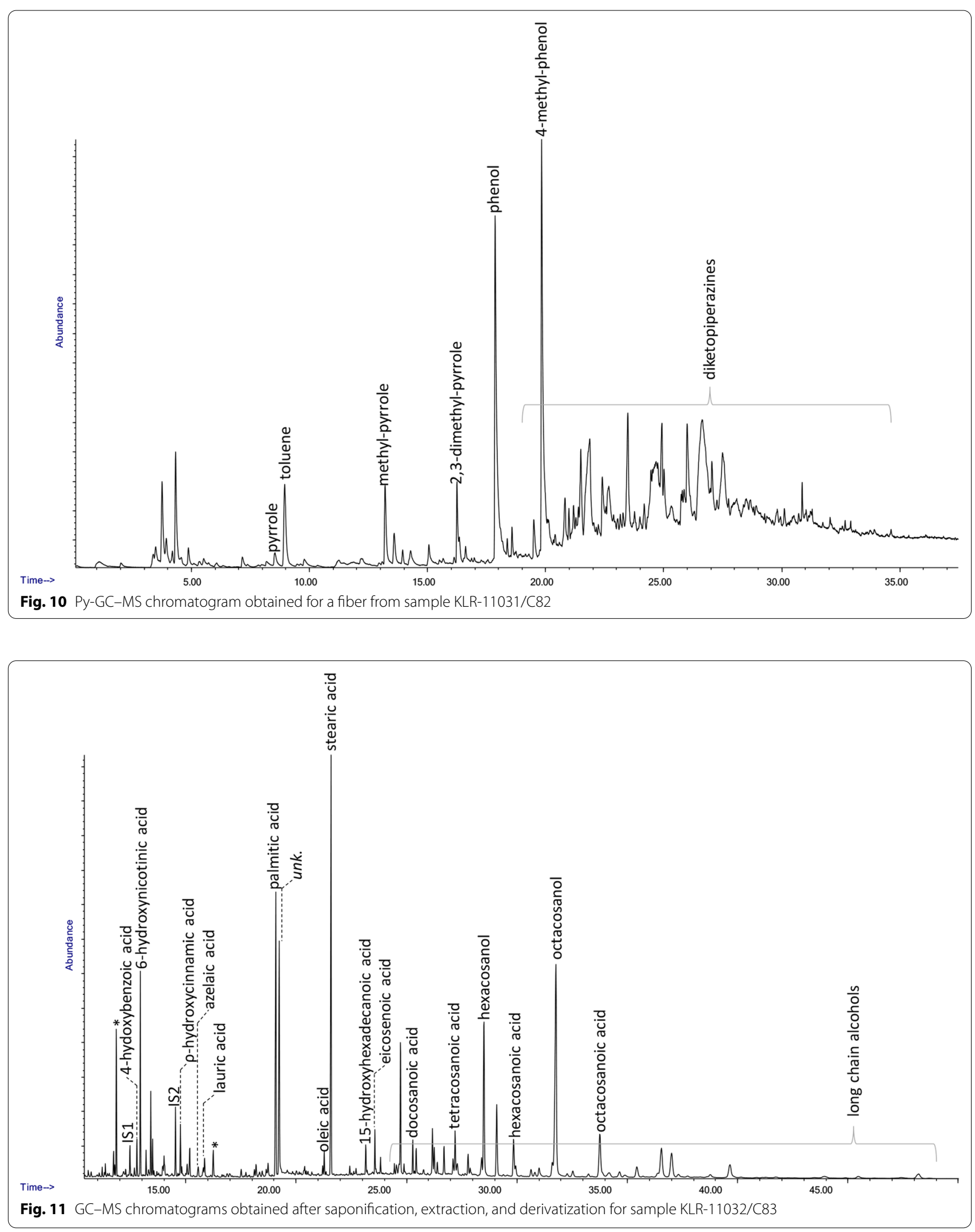

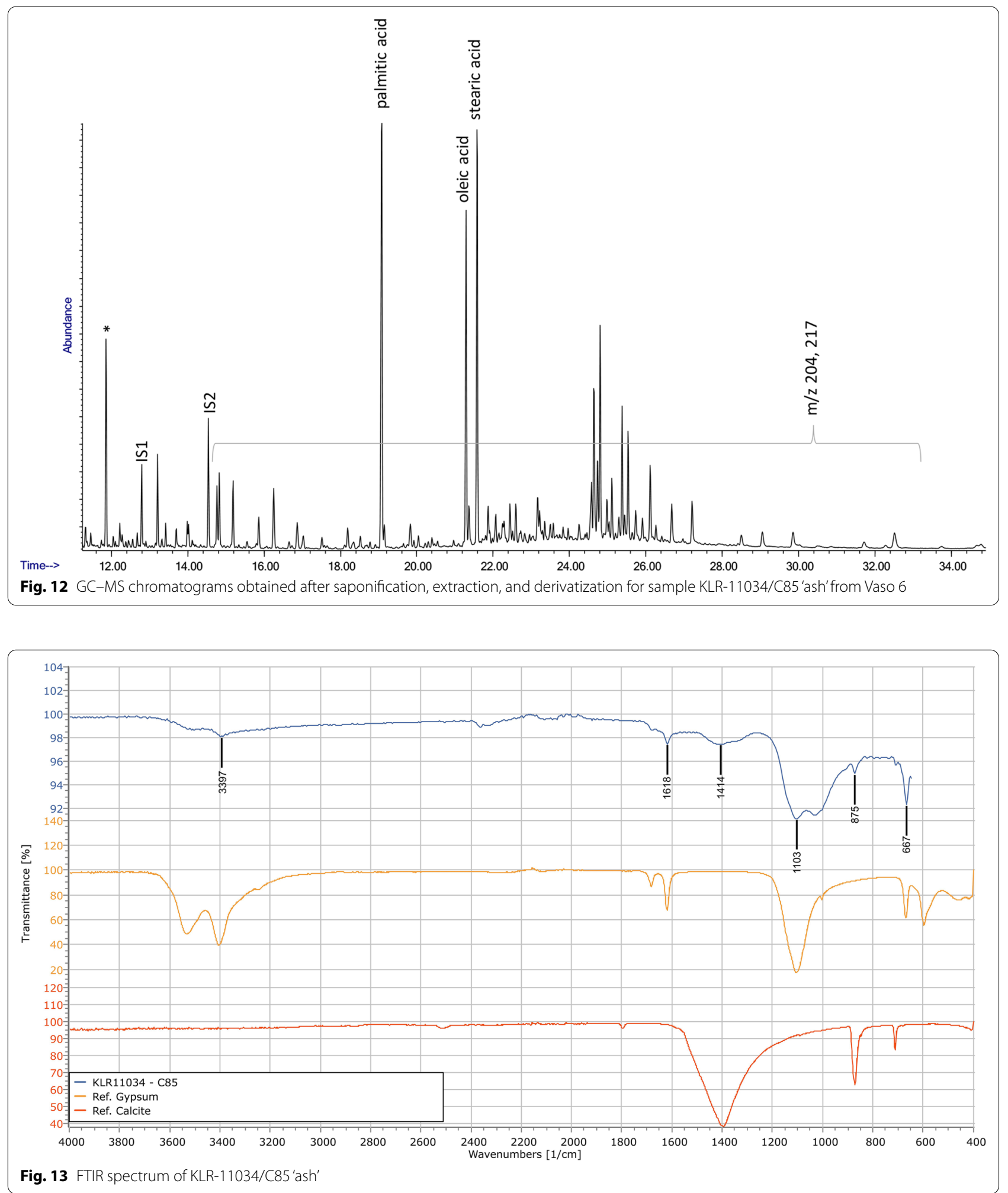


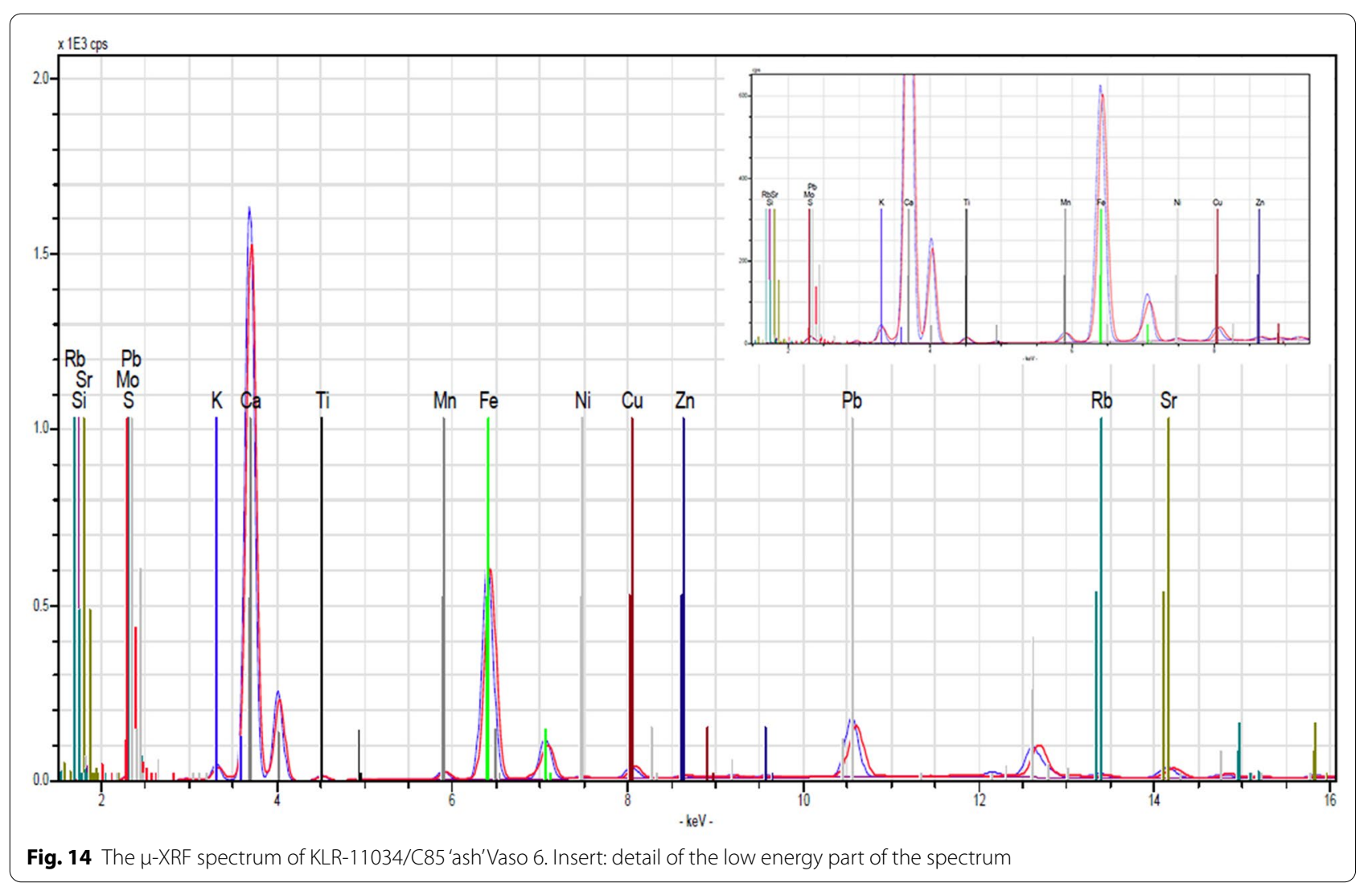

Table 5 Semi-quantitative results of the $\mu$-XRF analysis of sample KLR-11034/C85 'ash' Vaso 6

\begin{tabular}{lc}
\hline Element & $\begin{array}{l}\text { Conc. } \\
\mathbf{w t} \%\end{array}$ \\
\hline $\mathrm{Si}$ & 1.26 \\
$\mathrm{~K}$ & 1.15 \\
$\mathrm{Ca}$ & 24.5 \\
$\mathrm{Ti}$ & 0.13 \\
$\mathrm{Mn}$ & 0.05 \\
$\mathrm{Fe}$ & 1.55 \\
$\mathrm{Cu}$ & 0.04 \\
$\mathrm{~Pb}$ & 0.37 \\
\hline
\end{tabular}

The presence of beeswax was further confirmed by FIAESI-Q-ToF analyses. The presence of 6-hydroxynicotinic acid, a compound synthesized from 1956 and widely used in the production of insecticides [61] (Fig. 11).

\section{Analyses of the Vaso 6 sample marked 'ash' KLR-11034/C85}

The GC-MS analyses of a sample from Vaso 6 named 'ash' KLR-11034/C85 were highlighted by the presence of long chain $\alpha, \omega$-dicarboxylic and carboxylic acids that can be associate with the presence of suberin (Fig. 12).
FTIR analysis was also performed on the Vaso 6 'ash' sample (Fig. 13). This shows that the only major components visible by this technique are gypsum and calcite.

The $\mu$-XRF spectrum of KLR-11034/C85 'ash' Vaso 6 is depicted in Fig. 14 and the semi-quantitative analysis results are listed in Table 5.

The XRD pattern of the Vaso 6 KLR-11034/C85 sample is shown in Fig. 15. The amounts present is estimated by RIR calculation to be calcite: $52 \mathrm{wt} \%$; gypsum: $31 \mathrm{wt} \%$; diopside: $14 \mathrm{wt} \%$; Quartz: $3 \mathrm{wt} \%$.

\section{Radiocarbon dating the bone sample and the oil extract} The bone sample of St James KLR-11251a/C94 was investigated for contaminants prior to radiocarbon dating. A thoroughly mechanically decontaminated cortical sample from the femur was analysed by Py-GC-MS at Pisa University. The results of the analyses indeed revealed the presence of a foreign organic material, and a thorough decontamination was therefore called upon prior to radiocarbon dating.

The result of the Oxford radiocarbon date (OxA-38266) is listed in Table 6. The stable isotope ratios $\delta^{13} \mathrm{C}$ and $\delta^{15} \mathrm{~N}$ of the bone were $-19.25 \%$ ond $11.3 \%$, respectively. The $\delta^{13} \mathrm{C}$ value is indicative for a terrestrial diet of the individual. After that, a second sample of ca $700 \mathrm{mg}$ of 


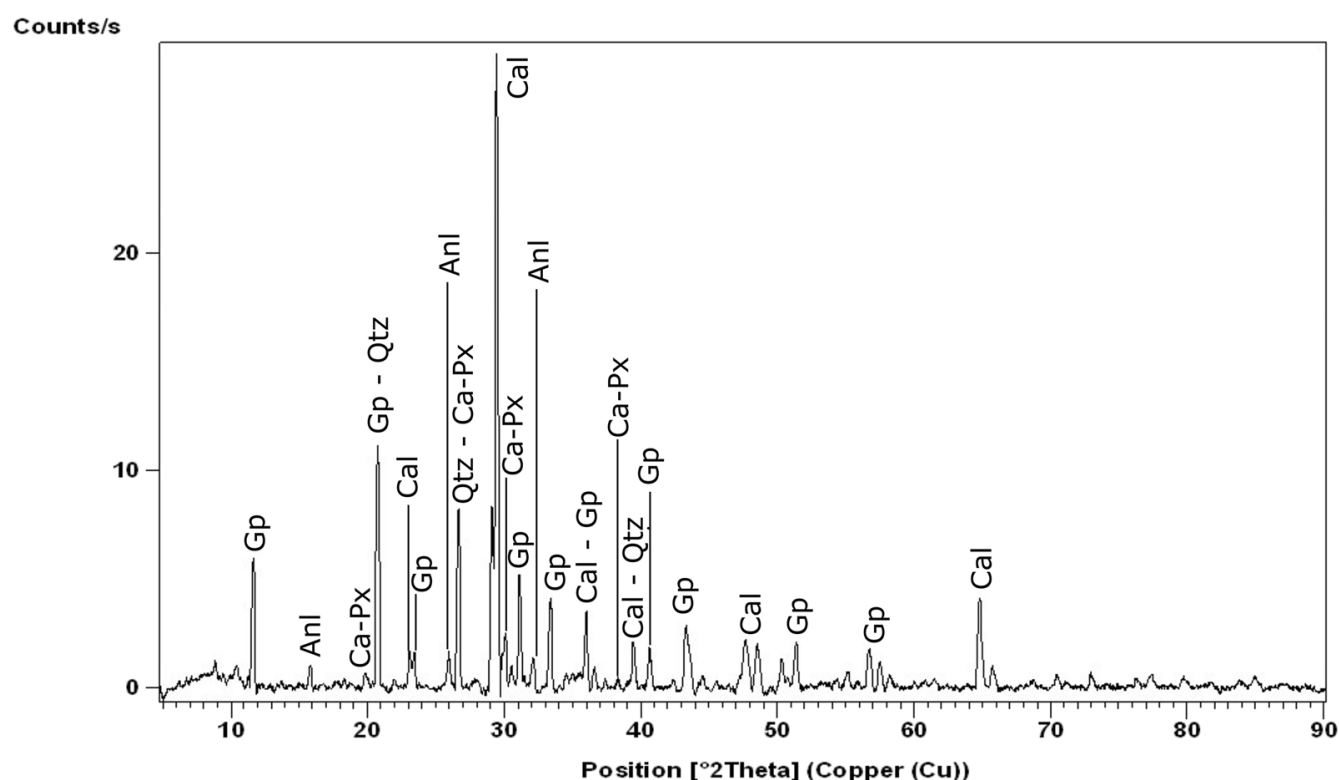

Fig. 15 XRD pattern of the sample KLR-11034/C85 'ash'Vaso 6. The following abbreviations are used: Cal, Calcite; Sp, Sphalerite; Brt, Barite; Qtz, Quartz; Gp, Gypsum; Di, Diopside

Table 6 Results of the radiocarbon dating

\begin{tabular}{lllllll}
\hline Lab No. & Lab No. & DSA No. & $\begin{array}{l}\boldsymbol{\delta}^{\mathbf{1 3}} \mathbf{C} \\
\mathbf{\% o}\end{array}$ & $\begin{array}{l}\text { C14 date } \\
\text { BP }\end{array}$ & $\begin{array}{l}\text { Calibrated at } \pm \mathbf{1} \boldsymbol{\sigma} \\
\text { Cal. AD }\end{array}$ & $\begin{array}{l}\text { Calibrated at } \pm \mathbf{2} \boldsymbol{\sigma} \\
\text { Cal. AD }\end{array}$ \\
\hline OxA-38266 & KLR-11251a & C94 & -19.25 & $1787 \pm 26$ & $238-254 ; 287-324$ & $214-261 ; 276-340$ \\
OxA-39529 & KLR-11251a & C94 & -30.50 & $1789 \pm 20$ & $238-253 ; 290-320$ & $219-259 ; 280-330$ \\
GrM-21736 & KLR-12290 & C93 & -29.74 & $1641 \pm 30$ & $401-438 ; 462-477 ; 498-533$ & $267-272 ; 361-539$ \\
\hline
\end{tabular}

The sample KLR-11251a/C94 is cortical bone tissue from St James. KLR-12290/C93 is an extract of the organic phase from the encrustation coating found in the canal. The $\delta^{13} \mathrm{C}$ is the stable isotope ratio measured by IRMS. The ${ }^{14} \mathrm{C}$ dates are calibrated into calendar ages using the IntCal20 curve [50]

Table 7 Results of the TL-dating and determination of radioactive isotopes

\begin{tabular}{|c|c|c|c|c|c|c|c|c|c|}
\hline KLR-No. & Material & $\begin{array}{l}\text { Date } \\
\text { AD y }\end{array}$ & $\begin{array}{l}1 \sigma \\
y\end{array}$ & $\begin{array}{l}\mathrm{U} \\
\mu \mathrm{g} \mathrm{g}\end{array}$ & $\begin{array}{l}1 \sigma \\
\mu g^{-1}\end{array}$ & $\begin{array}{l}\text { Th } \\
\mu \mathrm{g} \mathrm{g}^{-1}\end{array}$ & $\begin{array}{l}1 \sigma \\
\mu g g^{-1}\end{array}$ & $\begin{array}{l}\mathrm{K} \\
\mathrm{wt} \%\end{array}$ & $\begin{array}{l}1 \sigma \\
w t \%\end{array}$ \\
\hline KLR-12383 & Background & & & 0.70 & 0.03 & 4.81 & 0.24 & 1.95 & 0.10 \\
\hline KLR-12387 & Background & & & 1.06 & 0.05 & 7.10 & 0.35 & 1.26 & 0.06 \\
\hline Average & Background & & & 0.88 & 0.04 & 5.95 & 0.30 & 1.60 & 0.08 \\
\hline KLR-12381 & Shard & 530 & 108 & 4.15 & 0.21 & 8.99 & 0.45 & 2.04 & 0.10 \\
\hline
\end{tabular}

$1 \sigma$ is one standard deviation. The concentrations of $U$ and Th are listed in $\mu \mathrm{g} \mathrm{g}^{-1}$, that of $\mathrm{K}$ in wt\%

thoroughly mechanically decontaminated cortical bone was subjected to hydroxyproline dating also at Oxford. The resulting date (OxA-39529) was quite similar to the ultrafiltration date (see Table 6). Here the $\delta^{13} \mathrm{C}$ value was unexpectedly negative, no less than $-30.5 \%$.

Approximately $100 \mathrm{mg}$ of organic material were extracted in Pisa from the encrustation sample, and then shipped to Groningen for radiocarbon dating (based on graphite). The result (GrM-21736) is also shown in Table 6.

\section{TL-dating of the shard}

The results of the measurements are listed in Table 7. It was assumed that the shard has rested on the surface with air above it during the centuries in a manner similar to how it was found. This means that the radiation from 
the background can be calculated as half of the determined concentration values of the radioactive isotopes of U, Th, and K, called "Average Background" in Table 7. The water content of KLR-12381/C101 was determined to $1 \mathrm{wt} \%$. The cosmic radiation dose was assumed to be $180 \pm 30 \mu \mathrm{Gy}$ years $^{-1}$. The alpha efficiency was assumed to be $0.08 \pm 0.02$. Corrections for self-shielding were applied. The grain size was assumed to be $200 \pm 100 \mu \mathrm{m}$, and the density was estimated to be $1.8 \mathrm{~g} \mathrm{~cm}^{-3}$. Three sub-sample was each measured four times and averaged; Table 7 shows the average values. The average TL-age is calculated to be $530 \pm 108(1 \sigma) \mathrm{AD}$.

\section{Discussion}

\section{Chemical analyses of skeletal and mummy materials Mercury}

Twelve bone and mummy samples were analysed for $\mathrm{Hg}$ (see Table 2). From the femur of St James (KLR-11251/ C94) it is obvious that the surface, which exhibits a $\mathrm{Hg}$ concentration of no less than 20,870 $\mathrm{ng} \mathrm{g}^{-1}$, has been treated with a Hg-containing substance. It is likely that the $\mathrm{Hg}$ also penetrated into the trabecular tissue, which showed a concentration of $4460 \mathrm{ng} \mathrm{g}^{-1}$, whereas the cortical tissue by its $42.2 \mathrm{ng} \mathrm{g}^{-1}$ is below what is generally considered the environmental background of ca. $80 \mathrm{ng} \mathrm{g}^{-1}[34,62]$. Thus, the cortical femoral tissue has not been contaminated by the $\mathrm{Hg}$ treatment. Judging from these numbers, it is not a case of medical treatment [35, 63], but instead of a posthumous Hg-treatment. Possibly some of the $\mathrm{Hg}$ is originating from the application of cinnabar containing paint, the traces of which can still be seen on the surface of the bone (Fig. 16).

The three textile fragments from Vaso A, Vaso 1, and Vaso 2 (KLR-11031/C82, KLR-11032/C83, KLR-11033/ C84) and the sample of 'ash' from Vaso 6 (KLR-11034/

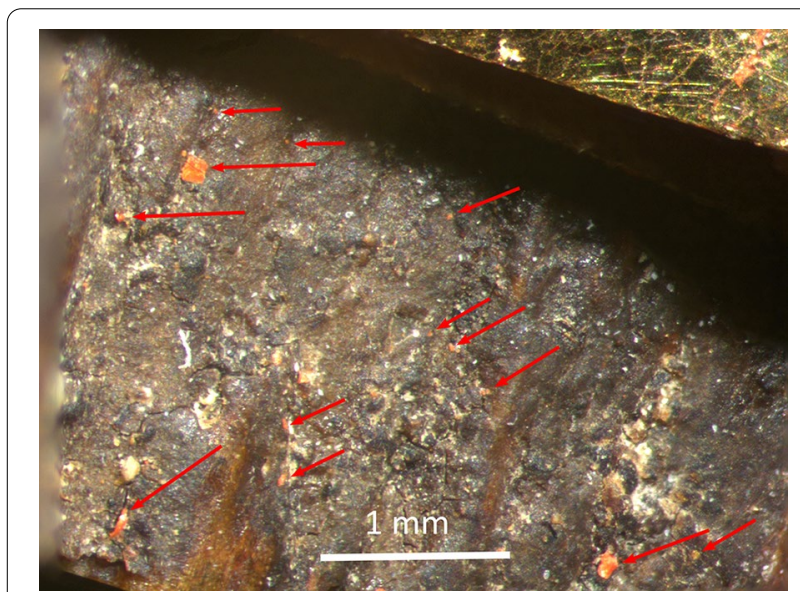

Fig. 16 Cinnabar applied to the exterior of the bone of St James KLR-11251/C94 (Photo: KLR)
C85) have also been analysed for Hg. All four exhibit extremely high concentrations of $\mathrm{Hg}$ varying from 11,228 to $68,668 \mathrm{ng} \mathrm{g}^{-1}$, which most likely is a sign of past conservational treatment. This is also the case for a sample of the skin from the upper side of the foot of St Philip (KLR11029/C80), showing an extremely high Hg concentration of $309,801 \mathrm{ng} \mathrm{g}^{-1}$. The sample of cortical tibia tissue from St Philip (KLR-11036/C90) shows a Hg concentration of $968 \mathrm{ng} \mathrm{g}^{-1}$, which is a factor of ca. ten higher than the environmental threshold of $\mathrm{ca} .80 \mathrm{ng} \mathrm{g}^{-1}$. However, it is also within the range of typical cortical tissue concentrations seen in medicated individuals from medieval Europe $[35,62,63]$. Nevertheless, the $\mathrm{Hg}$ in this sample could still originate from conservational efforts. It has not been established when the practice of treating certain diseases, most notable leprosy and syphilis, with $\mathrm{Hg}$ was initiated.

The present samples have been relics of the Holy Catholic Church for centuries. It is therefore a distinct possibility that several attempts at conservation have taken place during this time. Mercury has been found in corpses and tombs on numerous occasions: San Francesco Caracciolo [64], Tycho Brahe [65, 66], Agnès Sorel [67], several 1700 's aristocratic citizens of Moscow [68, 69], Anastasia Romanov [70], and Ferdinand II of Aragon and King of Naples [71]. It is therefore not surprising that $\mathrm{Hg}$ is found in great concentrations in the textiles and on the exterior of the mummy parts in the present study. It is more difficult to assess with certainty when the Hg conservational treatment of the relics from Santi Apostoli took place.

Looking at the other known cases, Agnès Sorel, who died during childbirth in 1450, could have been medicated with $\mathrm{Hg}$-containing medicine [67]. The same applies to aristocratic citizens of Moscow [68, 69] and many other people in medieval and post-medieval Denmark and Germany [35, 62]. Some may actually have been administered lethal doses of $\mathrm{Hg}$, like Anastasia Romanov [70]. Proven cases of posthumous conservational treatment, as in contrast to medical treatment or poisoning while still alive, probably conducted by the undertakers date from 1516 (Ferdinand II of Aragon), 1601 (Tycho Brahe), and 1608 (St Francesco Caracciolo). Although this is not a very certain basis, it is possible that we see indications that the conservational treatment of the relics at Santi Apostoli with $\mathrm{Hg}$ took place after ca. 1500 .

\section{Other trace elements}

The elements $\mathrm{Al}, \mathrm{Mn}$, and $\mathrm{Fe}$ are normally considered to be diagenetic when their concentrations are higher than certain threshold values. In particular this is observed in the samples of trabecular and surficial bone in the 


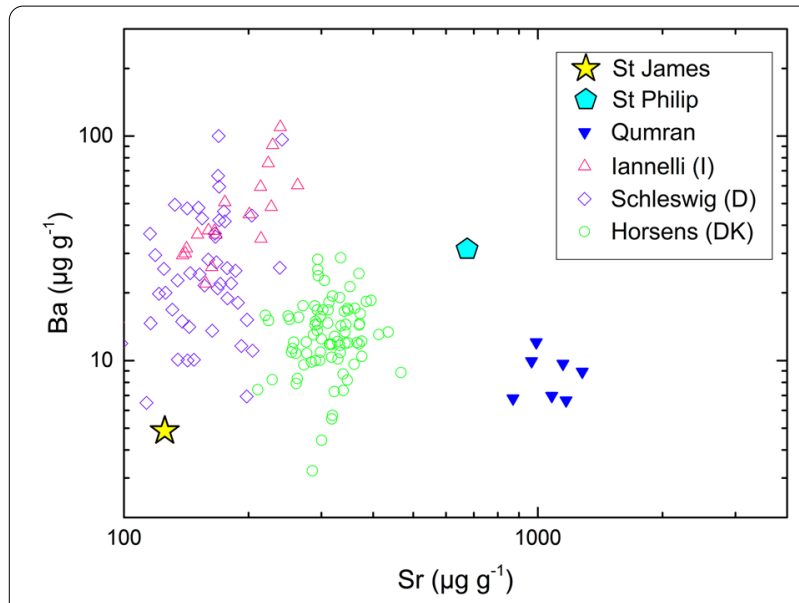

Fig. 17 Strontium versus Ba in cortical bone tissue from samples of St James and St Philip compared to three data sets from European cemeteries arbitrarily selected from Denmark (DK), Germany (G) and Italy (I), and to seven individuals interred at the cemetery at Qumran

present study (Table 3). Therefore, we considered the cortical tissues the best and the most pristine material suited for inferences of a biogenic signal.

The measurements of the concentrations of the elements $\mathrm{Cu}, \mathrm{Sr}, \mathrm{Ba}$, and $\mathrm{Pb}$ in cortical tissue of the two apostles allow a comparison with other bone analyses. Strontium and $\mathrm{Ba}$ can be interpreted as indicators for the diet and therefore possibly also the provenance [72-78]. In Fig. 17 the $\mathrm{Sr}$ and Ba concentrations of St James and St Philip are compared with four independent data sets: skeletons from a cemetery in Horsens (Denmark), a cemetery from Schleswig (Germany), skeletons from a noble family from Montella (AV, Italy) [36,80-82 and references therein], and perhaps most relevant the cemetery site of Qumran (Israel). The latter burials are closer in both age and geographical site to the apostles [79]. The Qumran samples were re-analysed in this work to yield also $\mathrm{Ba}, \mathrm{Cu}$, and $\mathrm{Pb}$. However, it should be noted that the bones from Qumran can well have been subjected to diagenesis, as these bones were devoid of collagen and have likely been in an oxidizing environment due to the low burial depth. It is not known how diagenetic changes in the desert environment would have affect the trace element concentrations, if at all.

Lead and $\mathrm{Cu}$ have been interpreted as indicators of social class or degree of urbanisation in the European middle age [34, 80-82]. High $\mathrm{Cu}$ concentrations in bone have been interpreted as indicative for a diet rich in meat, but it can also be obtained from other kinds of food as well [83-87]. High levels of $\mathrm{Cu}$ have also been observed in diets rich in cereals and vegetables [73]. However, some consider $\mathrm{Cu}$ as ambiguous with respect to dietary composition [88]. As an illustration, Fig. 18 shows a

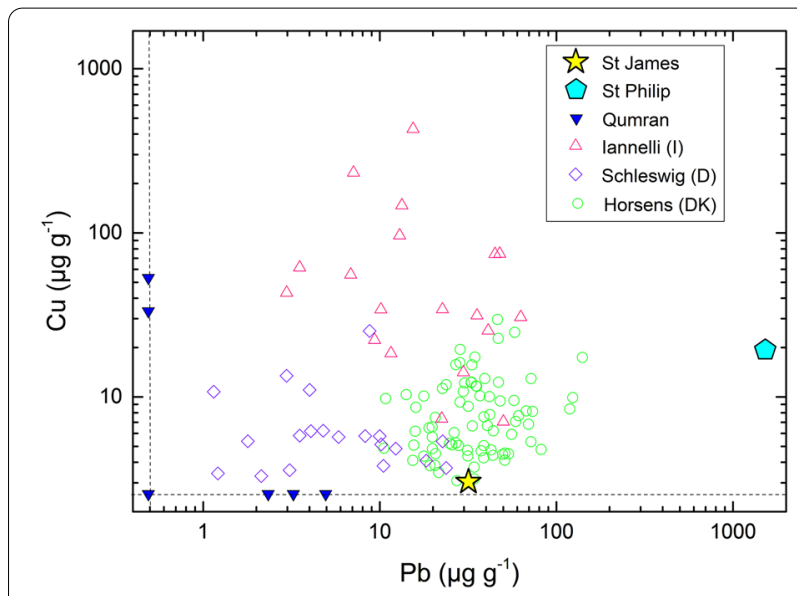

Fig. 18 Lead versus Cu in cortical bone tissue from samples of St Philip (solid yellow star) compared to three randomly selected data sets from Europe as well as seven individuals from Qumran. Some of the $\mathrm{Cu}$ and $\mathrm{Pb}$ concentration of the Qumran individuals were below LOQs, but the point is plotted at the LOQs (dashed lines)

comparison between the data from St James and St Philip and the same four widely different data sets described above.

Summarizing the chemistry of the cortical bones, compared with other European skeletons that of St Philip appear high in $\mathrm{Sr}$ and $\mathrm{Pb}$, while similar in $\mathrm{Cu}$ and $\mathrm{Ba}$. The very high Sr concentration found in St Philip is extraordinary and must mean that his diet was very special, at least according to European standards, and it is fitting better with the Qumran individuals. Alternatively, it could the results of a diagenetic process. The high $\mathrm{Pb}$ concentration in St Philip can be the result of different environmental exposures and is therefore perhaps not so spectacular. The probability that these trace element concentrations are severely affected by diagenesis is reduced by the normal values of the $\mathrm{Cu}$ and $\mathrm{Ba}$ concentrations.

St James was not exposed to $\mathrm{Cu}$ and was quite similar in $\mathrm{Pb}$ to many of the European skeletons. His bones appear low in $\mathrm{Sr}$ and low Ba concentrations, which-had he been a European-was indicative of a high social class with a meat-rich diet [89]. Again, the low concentration values make it less likely that the bone has been affected by diagenesis.

For KLR-11034/C85 the 'ash' from Vaso 6 and KLR11036/C90 bone fragments from St Philip are observed As-concentrations almost 100 times higher than the rest of the samples. The $\mathrm{Pb}$ concentrations are also elevated for these two samples, by a factor of approximately 10 to 50. These two samples have likely been conserved with a compound holding a mixture of $\mathrm{Pb}$ and As. It is not possible to ascertain at what time this conservational treatment took place. For the Vaso 6 material, it could be 
either before or after the incineration if the word 'ash' is to be taken literally.

\section{The organic analyses}

The embalming material of St Philip (KLR-12288/C18) had a fatty acid profile, dicarboxylic acids, vegetable sterols, which were all characteristic of a vegetable oil (Fig. 9). The analyses also showed the presence of several hydroxy acids associated with the skin fat of the mummy. The GC-MS analyses also showed the presence of traces of erucic acid, which can be associated with rapeseed oil: even if this fatty acid is a specific marker of this type of lipid material, the presence of the mummy hydroxy fatty acids, similar to those characteristic of aged rapeseed oil, does not on itself allow an identification. However, taken together with the FIA-HRMS analyses, the presence of both rapeseed oil and beeswax can be established. The GC-MS analyses also showed the presence of pimaric, dehydroabietic, and abietic acids, associated with pine resin. Finally, the GC-MS analyses also showed the presence of phenol, cinnamic, and vanillin derivatives that can be associated with flowers or wood. So, it seems these mummy parts were that of a decaying body, with pine resin and fragrances, and rapeseed oil, all of which must be characterized as typical for embalming purposes.

The visually disintegrated 'textile' sample in Vaso 2 (KLR-11032/C83) showed the presence of beeswax and traces of insecticides. Both beeswax and the insecticides were probably originating from an attempt of conversation, which for the insecticides likely took place in 1956 or thereafter.

The textile in Vaso A KLR-11031/C82 was analysed by Py-GC-MS which showed that the fiber was characterized by the presence of pyrrole derivatives, phenols, and diketopiperazines, a profile consistent with silk.

The blackened surface on the inside of the lower side of the big box consistently showed the presence of carbon black as well as traces of rapeseed oil. It therefore seems quite safe to conclude that there has been a fire inside the small box, where rapeseed oil has been put aflame. Whether the burnt oil is the same as the oil identified in the encrustation has not been ascertained. Why, or at what time, the fire took place cannot be deducted by the present study. It can be speculated that perhaps the incinerated material in Vaso 6 was burned at the time of the fire in the small box, but again there is no way to find this out with certainty from the present investigation.

The sample in Vaso 6-Philip (KLR-11034/C85 'ash') - is somewhat enigmatic. The GC-MS analyses showed the presence of suberin, which is a material normally found in the bark of trees. The ICP-MS analysis showed large quantities of $\mathrm{Ca}$ (16.5 wt\%), and remarkably high concentration of $\mathrm{Sb}$ and $\mathrm{Pb}\left(31.7 \mu \mathrm{g} \mathrm{g}^{-1}\right.$ and $3500 \mu \mathrm{g} \mathrm{g}^{-1}$ respectively). The results of XRD and $\mu$-XRF analyses showed 20.8 and 24.4 wt\% Ca, respectively. The discrepancy between the Ca-determinations is probably due to inhomogeneities in the sample. It is noteworthy that the XRD pattern is devoid of hydroxyapatite, which means that there is no bone dust in the sample. Rather, there are abundant amounts of gypsum and calcite $\left(\mathrm{CaSO}_{4} \cdot 2 \mathrm{H}_{2} \mathrm{O}\right.$ and $\mathrm{CaCO}_{3}$ ), which can also be seen to be the only major components in the FTIR spectrum (Fig. 13).

It is therefore possible that the sample consisted of ash of decayed wood mixed with calcite and gypsum which was rich in $\mathrm{Sb}$ and $\mathrm{Pb}$. The pertinent questions are what the wood were used for, why it had been burned, and what role the calcite/gypsum mixture played. None of these questions are easy to answer. A proper interpretation of the Vaso 6 material is left for future research.

\section{The encrustation from the canal in the big hole}

The large amounts of calcium carbonate in the encrustation identifies it without much doubt as a deposit from running water. Embedded in the porous and brittle encrustation was identified rapeseed oil, which was of a chemical composition indicative of an oil from nonmodern times. The radiocarbon dating of the extracted oil gave a date of AD 267-539 (2б). It cannot be inferred either where the oil came from, nor what its purpose was, but it is likely that the oil was part of the relics associated with St James and St Philip right from start when the relics came to Rome.

\section{The dating of the altar and the dating of the bones}

A pertinent question is at what date the reliquary was erected. As mentioned above, the present church was built in the third quarter of the 6th Century. However, it is possible that another architectural structure was present at the site prior to the erection of the church.

The bones and mummy parts of the apostles-if these are indeed from the apostles-have for sure been transported from some previous location to the site of the Santi Apostoli. Not necessarily to a preceding church or the one erected in the 6th Century, but possibly to a preceding crypt or building at the site. The ceramic shard has at some point been part of a ceramic vessel. It can have contained the oil identified in the encrustation, which in itself surely was part of the altar construction. The encrustation, however, cannot have been moved from a previous location due to its brittle nature. The ceramic vessel, possibly including the oil, can have been transported from elsewhere and into the site of Santi Apostoli, and when it broke, the oil released could have been absorbed and preserved in the pore spaces of the encrustation. 


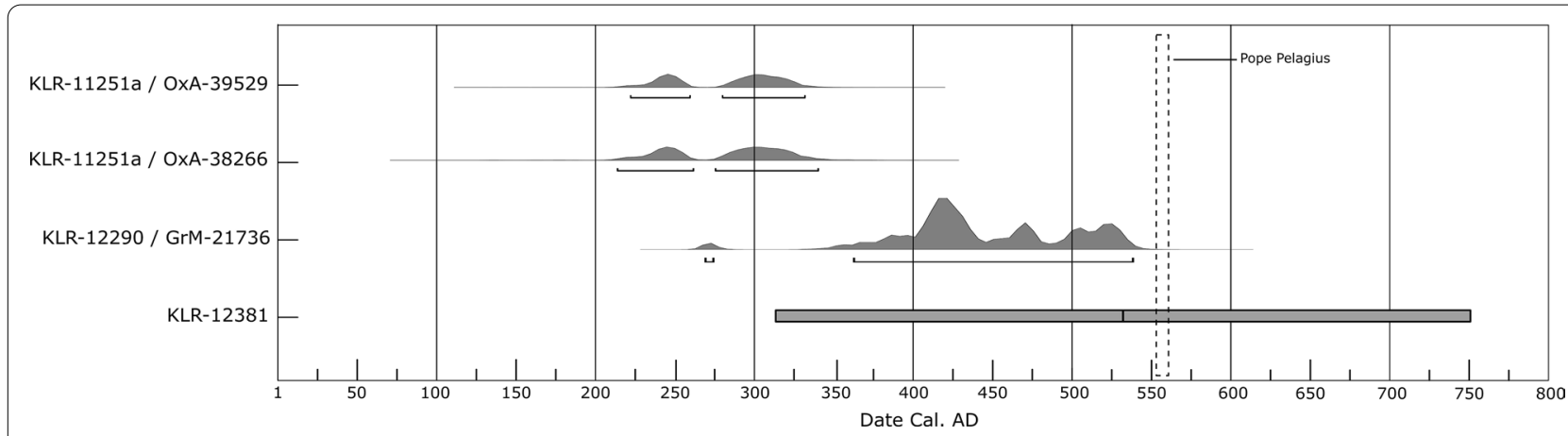

Fig. 19 The results of the calibration of the radiocarbon dates and the TL-date. The IntCal20 curve has been used [50]. The bars indicate 2ఠ. The papacy of Pope Pelagius I 556-561 is marked with a dashed rectangle

How does this perception fit with the sequence of dates produced in this study? The bone of St James was radio-

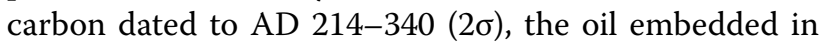
the encrustation was radiocarbon dated to AD 267$539(2 \sigma)$, and the shard TL-dated to AD 314-746 $(2 \sigma)$ (Fig. 19).

The most important conclusion of our in-depth investigation of the age of the bone sample is that the relic cannot belong to St James. The radiocarbon dates of both ultrafiltrated collagen and the hydroxyproline fraction are identical. In addition, the stable isotopes measurements yield $\delta^{13} \mathrm{C}=-19.25 \%$ and $\delta^{15} \mathrm{~N}=11.3 \%$ for OxcA-38266. These stable isotope values are indicative of the food source of the individual. The $\delta^{15} \mathrm{~N}$ value is elevated (see e.g. [90, 91].). This may be caused by intake of fish, in which case there could be a reservoir effect making the measured radiocarbon date appear too old. If that was the case, the fish must be of freshwater origin and not marine, considering the $\delta^{13} \mathrm{C}$ value $[92,93]$. However, in arid regions plants and animals can also be elevated in $\delta^{15} \mathrm{~N}$ for other reasons [94]. Therefore, another possibility could be intake of veal or goat, because organisms subject to weaning also show elevated $\delta^{15} \mathrm{~N}$ values [95]. Thus, for a human consuming a significant amount of meat from veal or young desert sheep/goat the $\delta^{15} \mathrm{~N}$ will be enhanced. We consider the intake of freshwater fish less likely than the later mentioned food items, in which case there is no reservoir effect and therefore the radiocarbon dates show the correct age of the bone.

But even if we assume that we have to deal with a freshwater reservoir effect, the ${ }^{14} \mathrm{C}$ date then would show an apparent age; the true age of the individual would be younger. This also excludes the relic from belonging to St. James.

One unexpected number is the $\delta^{13} \mathrm{C}$ of the hydroxyproline date (OxA-39529) of $-30.5 \%$. However, $\delta^{13} \mathrm{C}$ values of hydroxyproline dated bone samples from the Oxford
AMS laboratory have been seen to vary from -21 to -31 $\%$ (prof. Tom Higham, personal communication) for a reason that is unclear. It is important to note that the reported stable isotope values were measured by IRMS. In general, the AMS also measures a separate $\delta^{13} \mathrm{C}$ value, which is used for isotopic fractionation correction of the ${ }^{14} \mathrm{C}$ date. This value is normally not reported. In the case of St James, however, it is important to observe that this AMS $\delta^{13} \mathrm{C}$-value confirms the one measured by IRMS. That means the low $\delta^{13} \mathrm{C}$ value is the true value for the dated compound, and the fractionation correction for the ${ }^{14} \mathrm{C}$ date is therefore correct.

Thus, the preserved relic is not that of St James. With the date of $\mathrm{AD} 214-340(2 \sigma)$ the preserved skeletal remains originate from an individual some $130-260$ years younger than St James.

Returning to the sequence of events, the oil in the

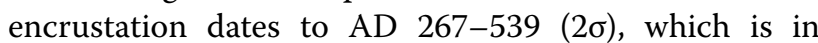
accordance with the date of the relic (AD 214-340, 2 $\sigma$ ), and the date of the shard (AD 314-746, 2 $\sigma$ ). From a statistical point of view, consequently, a hypothesis that all three samples are similar in age is acceptable. In a historical context this is, however, unlikely. When the early church authorities were searching for the corpse of an apostle who lived a couple of hundred years earlier, they would look in ancient burial grounds where bodies of holy men might have been put to rest. Accordingly, the bone of the assumed St James was presumably older than the oil and the shard, which was used for the veneration of the relic once the body was recovered.

The use of relics such as those of the church of Santi Apostoli should be placed in the wider cultural context and in the rise of interest in relics of martyrs and saints. The origins of this activity should be searched for in the increasing practice of saint veneration among Christians and their adoption of the Roman practice of sharing meals with the dead beside the grave as a way of 
honouring the saints at their tombs [96]. Until the middle of the 4th Century, martyr tombs were important worship places. They were usually located outside the city walls, so that worship places and churches in the city itself were physically separated. The translation of bones starting in the second half of the 4th Century intended to end this undesirable separation. The increasing number of believers may also have played a role, since it implied a necessary expansion of tomb shrines into cemetery churches [97]. The first translation we know of is that of St Babylas in AD 354 [24], whose remains were transferred from a cemetery in Antioch to Daphne and placed in a church especially built for the purpose by governor Caesar Gallus [98]. Immediately afterwards, translations got popular: the translations of St Timotheus, St Andrew, and St Lukas to Constantinople followed one another in a year's time [99].

At the same time, our sources reflect an increasing popularity and circulation of relics from the second part of the 4th Century onwards. Despite the criticism of bishop Athanasius of Alexandria († 373) and Shenoute († 465) at the end of the same century and in the following, relics of martyrs and saints began to be moved into the churches $[100,101]$. Throughout the Roman empire, bodies or body parts were exhumated, transferred, and reburied in the apse in close vicinity of the altar. So much so that the authorities felt the need to promulgate edicts imposing penalties on those who contravened them and violated tombs, such as that by Constantius II in AD 340-356 [99] or prohibiting the translation of bodies and the selling of relics such as those of Valentinian II, Theodosius I, and Arcadius (AD 386; Cod. Theod IX.17.7). This is also well attested in the West. Despite prohibitions, after a revelation in a dream bishop Ambrose of Milan (AD 340-397) managed to move Gervasius' and Protasius' remains to his own basilica. He placed them under the altar, in a place originally destined for bishop Ambrose himself. Paulinus from Nola recorded that Ambrose conducted two more translations, those of St Nazarius (Vita Sancti Ambrosii 32, in PL 14, 29-50, at col. 40CD) and Vitalis and Agricola, who were moved from Bologna to a new basilica in Florence (Vita Sancti Ambrosii 29, at col. 39C). On the other hand, he also mentioned how (secondary) relics were being distributed at that time through networks of the bishops for the sake of glorifying their churches (Vita Ambrosii 33 at col. 41B).

The relics of SS James and Philip may have originated in a similar context. We do not know who found them and/ or brought them to Rome. The fact is, however, that they came to glorify the current church of Santi Apostoli constructed in their honor. The close connection between altar and relics assured a link between the saints and the ritual, in the same way that it used to happen with the veneration of the saints at their graves. The date of the relics agrees with this hypothesis. If we consider the founding of the church by Pope Pelagius in AD 556-561 as a terminus ante quem (see dashed rectangle in Fig. 19), then the bones may at that time have been between 236 and 318 years old $(1 \sigma)$. The radiocarbon date of the rapeseed oil in the encrustation was only 23 to 155 years old $(1 \sigma)$ in AD 556, which, for the lower limit of 23 years, is within the boundaries of the accuracy of the radiocarbon dating method taking all possible uncertainties into consideration. The uncertainty of the TL-date of the ceramic shard is so wide, that it can easily fit the interpretation that the date is simultaneous with the papacy of Pope Pelagius I.

\section{Conclusions}

From the high altar in the Basilica dei Santi Apostoli in Rome, we analysed relics of the apostles St Philip and St James together with architectural samples. Various events of past conservational treatments have been established. The presence of $\mathrm{Hg}$ on the surficial mummy and textile samples, but not in the compact cortical femoral tissue, points at conservational treatment maybe as early as shortly after AD 1500. The mummy material in Vaso 2 contained beeswax and insecticides making one or two conservational treatments likely, one after 1956. The enigmatic sample in Vaso-6 is likely wood ash preserved or mixed with calcite, gypsum, and an $\mathrm{Sb}$ and $\mathrm{Pb}$ rich compound. Vaso 6 and the bone fragments of St Philip likely received a conservational treatment with As and $\mathrm{Pb}$.

The chemistry of the trace elements $\mathrm{Sr}, \mathrm{Ba}, \mathrm{Cu}$, and $\mathrm{Pb}$ in the bones of St Philip and St James was investigated, but a clear interpretation is indecisive due to the present lack of comparative bone analyses.

The bone relic of St James has been radiocarbon dated to $\mathrm{AD} 214-340(2 \sigma)$, and rapeseed oil extracted from the encrustation found in the canal in the high altar was

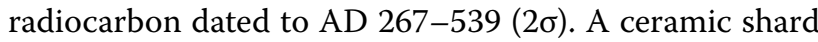
found in top of the ancient hole was TL-dated to AD $314-746(2 \sigma)$.

We conclude that the relic cannot belong to the "true" apostle St James.

\footnotetext{
Abbreviations

AMS: Accelerator Mass Spectrometry; BFSTA: N,O-Bistrifluoroacetamide; CV-AAS: Cold Vapour Atomic Absorption Spectroscopy; FIA-ESI-Q-ToF: Flow Injection Analysis-Electron Spray lonisation-Quadrupole-Time of Flight mass spectrometry; FTIR: Fourier Transform Infra-Red spectroscopy; GC-MS: Gas Chromatography Mass Spectrometry; HPLC-ESI-HRMS: High Performance Liquid Chromatography_Electron Spray lonisation—High Resolution Mass Spectroscopy; ICP-MS: Inductively Coupled Plasma Mass Spectrometry; IRMS: Isotope Ratio Mass Spectrometry; LOD: Limit of detection; LOQ: Limit of quantification; $\mu$-XRF: Micro-X-ray fluorescence; RIR: Reference intensity ratio; RSD:
} 
Relative standard deviation; SD: Standard deviation; XRD: X-ray diffraction; XRF: X-ray fluorescence.

\section{Acknowledgements}

The help and services of Thibaut Deviese and Tom Higham at the Oxford Radiocarbon laboratory are greatly appreciated. The help and support of Agnello Stoia, Nazzareno Gabrielli, and Ezio Fulcheri are greatly appreciated. We wish to thank Anita Aerts-Bijma and Pia Haussmann Klingenberg for technical help with the measurements. The authors are grateful to Dr. Stefano Legnaioli (National Research Council of Italy, Pisa, Italy) for performing the Raman spectroscopy analysis.

\section{Authors' contributions}

Conceived and designed the experiments: KLR. Performed the analyses: JvdP, $J L N, E R, L S, T D, K L R$. Field archaeology: SS and KLR. Acquired the historical sources: SS, UK, PGH, and LRL. Analysed the data: JvdP, JLN, ER, MPC, LS, TD, SS, UK, PGH, LRL. Wrote the paper, with comments from other participants: KLR, JvdP, UL, PGH, and LRL. The paper was approved by all authors. All authors read and approved the final manuscript.

\section{Funding}

No external funding was achieved for the project.

\section{Availability of data and materials}

Data are available upon request from the authors.

\section{Ethics approval and consent to participate}

No permission was required as all sample material was acquired through archaeological excavations.

\section{Competing interests}

The authors declare that they have no competing interests.

\section{Author details}

${ }^{1}$ Institute of Physics, Chemistry and Pharmacy, University of Southern Denmark, Campusvej 55, 5230 Odense M, Denmark. ${ }^{2}$ Center for Isotope Research, University of Groningen, Nijenborgh 6, 9747 AG Groningen, the Netherlands. ${ }^{3}$ Dipartimento Di Chimica E Chimica Industriale, Università Di Pisa, Via Giuseppe Moruzzi, 3, 56124 Pisa, Italy. ${ }^{4}$ Cranfield Forensic Institute, Cranfield University, Defence Academy of the UK, Shrivenham SN6 8LA, UK. ${ }^{5}$ Pontifical Institute of Christian Archaeology, Via Napoleone III, 1, 00815 Roma, Italy. ${ }^{6}$ National Museum of Denmark, Middle Ages, Renaissance \& Numismatics, Copenhagen, Denmark. ${ }^{7}$ Faculty of Theology and Religious Studies, University of Groningen, Oude Boteringestraat 38, 9712 GK Groningen, The Netherlands.

Received: 9 November 2020 Accepted: 4 January 2021

Published online: 29 January 2021

\section{References}

1. Duchesne L. Le liber Pontificalis: texte, introduction et commentaires 1. Paris. 1886. p. 303

2. Grisar H. L'Apostoleion di Costantinopoli e la basilica romana dei Santi Apostoli. In: Romana A, editor. Dissertazioni, testi, monumenti dell'arte riguardanti principalmente la Storia di Roma e dei Papi nel medio evo. Roma: Desclée Lefebvre e C Editori; 1899. p. 611-26.

3. Verrando GN. L'attivitá edilizia di papa Giulio I e la basilica al III Miglio della via Aurelia ad Callistum. Mélanges de l'école française de Rome. 1985;97(2):1021-61.

4. Mazzucco I. Iscrizioni della basilica e Convento dei Santi Dodici Apostoli in Roma. Roma: I'Apostoleion. 1987. p. 27-8.

5. Schelbert G. Der Palast von Ss Apostoli und die Kardinalsresidenzen des 15. Jahrhunderts in Rom. Norderstedt. Books on Demand. 2007. p. 80.

6. Diefenbach S. Römische Erinnerungsräume. Heiligenmemoria und kollektive Identitäten im Rom des 3. bis 5. Jahrhunderts n. Chr., Millennium-Studien 11. Berlin/New York: Walter de Gruyter. 2007:233 note 61.

7. Brandenburg H. Die frühchristlichen Kirchen in Rom vom 4. bis zum 7. Jahrhundert: der Beginn der abendländischen Kirchenbaukunst, 3. komplett überarb., aktualisierte dt. Aufl. Regensburg: Schnell + Steiner. 2013. p. 233.

8. Buchowiecki W. Handbuch der Kirchen Roms. Wien: Verlag Brüder Hollinek; 1967. p. 638-68.

9. Schelbert G. SS Apostoli a Roma. II coro-mausoleo rinascimentale e il triconco rinato, in Frommel S. (ed). La place du choeur : architecture et liturgie du Moyen Âge aux temps modernes, Itinéraires percorsi 1. Paris: Picard. 2012. p. 101-12.

10. Martyrium GA. Recherches sur le culte des reliques et l'art chrétien antique, I. Paris: Collège de France; 1946.

11. Krautheimer R. Corpus Basilicarum Christianarum Romae I. Roma: Città del Vaticano; 1937. p. 79.

12. Bufalini, map of Rome 1551. https://www.info.roma.it/pianta_di_ roma_1551_leonardo_bufalini.asp. Accessed 1 Oct 2020.

13. Ghersi LF. La basilica dei SS Apostoli a Roma. Storia, arte e architettura, Roma: Artemide. 2011. p. 31-56.

14. Reiss A. Rezeption frühchristlicher Kunst im 19. und frühen 20. Jahrhundert: Ein Beitrag zur Geschichte der Christlichen Archäologie und zum Historismus, Kasseler Studien zur Sepulkralkultur 13, Dettelbach: Verlag J. H. Röll. 2008. p. 137-45.

15. Schiavone SP, Lultimoriposodei SS. Filippo e Giacomo: Status quaestionis. San Bonaventura informa Anno IV. 2016;39:8-10.

16. Myllykoski M. James the just in history and tradition: perspectives of past and present scholarship (part II). Curr Biblical Res. 2007;6:11-98.

17. Trudinger LP. Heteron de ton apostolon ouk eidon, ei mē lakōbon ...: A Note on Galatians 1.19, NovT, vol. 17. 1975. p. 200-02.

18. Howard G. Was James an Apostle? A Reflection on a New Proposal for Gal i.19. NovT, vol. 19. 1977. p. 63-64.

19. Bruce FF. James and the Church of Jerusalem. Men and Movements in the Primitive Church. Exeter. 1977. p. 86-119.

20. Bauckham R. Jude and the Relatives of Jesus in the Early Church. London and New York: T\&T Clark; 2004. p. 20-7.

21. James B, Prothro JB. Semper Virgo? A Biblical Review of a Debated Dogma. Pro Ecclesia. 2019;28:78-97.

22. Flavius Josephus (Antiquitates Judaicae 20.200).

23. Origen. Fragment 126 of his Commentary on John.

24. Eusebius. Historia Ecclesiastica 2.23.

25. Watson JF. Philip 6-7. Anchor Bible Dictionary. 1992.

26. Clemens A. Stromateis. IV.73.3

27. De Santos Otero A. Acta Philippi. In: New Testament Apocrypha. Writings Related to the Apostles, Apocalypses and Related Subjects. Ed. Schneemelcher W and translated by Wilson RM. Cambridge-Louisville. 1992; II:468-473

28. Nag Hammadi Codex VIII,2.

29. Nag Hammadi Codex III,4.92.

30. Nag Hammadi Codex II,3.

31. Pistis Sophia (Askew Codex) 1:42.

32. Mazzucco I. Filippo e Giacomo Apostoli nel loro santuario romano: II sepolcro, le reliquie, il culto. Roma: L’Apostoleion; 1982.

33. Goodson CJ. Building for Bodies. The Architecture of Saint Veneration in Early Medieval Rome. In: Carragáin EÓ, Neumann C (eds.) Felix Roma: Formation and Reflections of Medieval Rome. Farnham: Ashgate. 2008:62-64.

34. Rasmussen KL, Skytte L, Jensen AJ, Boldsen JL. Comparison of mercury and lead levels in the bones of rural and urban populations in Southern Denmark and Northern Germany during the Middle Ages. J Archaeol Sci Rep. 2015;3:358-70.

35. Rasmussen KL, Skytte L, D'Imporzano P, Thomsen PO, Søvsø M, Boldsen $J$ L. On the distribution of trace element concentrations in multiple bone elements in 10 Danish medieval and post-medieval individuals. Am J Phys Anthropol. 2017;162:90-102.

36. Blanco-Zubiaguirre L, Ribechini E, Degano I, La Nasa J, Carrero JA, García-Iñañez J, Olivares M, Castro K. GC-MS and HPLC-ESI-QTOF characterization of organic lipid residues from ceramic vessels used by basque whalers from $16^{\text {th }}$ to $17^{\text {th }}$ centuries. Microchem J. 2018;137:190-203.

37. Orsini S, La Nasa J, Modugno F, Colombini MP. Characterization of Aquazol polymers using techniques based on pyrolysis and mass spectrometry. J Anal App Pyrolysis. 2013;104:218-25.

38. La Nasa J, Zanaboni M, Uldanck D, Degano I, Modugno F, Kutzke H, Tveit ES, Topalova-Casadiego B, Colombini MP. Novel application of liquid chromatography/mass spectrometry for the characterization of drying 
oils in art: elucidation on the composition of original paint materials used by Edvard Munch (1863-1944). Anal Chim Acta. 2015;896:177-89.

39. La Nasa J, Nardella F, Andrei L, Degano I, Colombini MP, Ribechini E. Profiling of high molecular weight esters by flow injection analysishigh resolution mass spectrometry for the characterization of raw and archaeological beeswax and resinous substances. Talanta. 2020;212:120800

40. Carlesi S, Ricci M, Cucci C, La Nasa J, Lofrumento C, Picollo M, Becucci M. Multivariate analysis of combined Fourier Transform Near-Infrared (FT-NIR) and Raman data sets for improved discrimination of drying oils. App Spec. 2015;69:865-76.

41. Lee J, Bonaduce I, Modugno F, La Nasa J, Ormsby B, van den Berg KJ. Scientific investigation into the water sensitivity of twentieth century oil paints. Microchem J. 2018;138:282-95.

42. La Nasa J, Degano I, Brandolini L, Modugno F, Bonaduce I. A novel HPLC-ESI-Q-ToF approach for the determination of fatty acids and acylglycerols in food samples. Anal Chim Acta. 2018;1013:98-109.

43. Menges F. Spectragryph - optical spectroscopy software, Version 1.2.14, 2020, http://www.effemm2.de/spectragryph. 2020.

44. Brock F, Higham T, Ditchfield P, Bronk Ramsey C. Current pretreatment methods for AMS Radiocarbon dating at the Oxford Radiocarbon Accelerator Unit (ORAU). Radiocarbon. 2010:103-112.

45. Tripp JA, Devièse T, McCullagh JSO. Preparative HPLC Separation of Underivatized Amino Acids for Isotopic Analysis. In: Alterman M (Ed.) Amino Acid Analysis. Methods in Molecular Biology. New York: Humana. 2019;2030. https://doi.org/10.1007/978-1-4939-9639-1_7.

46. Bronk RC. Bayesian analysis of radiocarbon dates. Radiocarbon. 2009;51:337-60.

47. Synal H-A, Stocker M, Suter M. MICADAS: A new compact radiocarbon AMS system. Nucl Instr Meth Phys Res B. 2007;259:7-13.

48. Aerts-Bijma AT, van der Plicht J, Meijer HAJ. Automatic AMS sample combustion and $\mathrm{CO}_{2}$ collection. Radiocarbon. 2001;41:293-8.

49. van der Plicht J, Hogg A. A note on reporting radiocarbon. Quat Geochronol. 2007;1:237-40.

50. Reimer PJ, Austin WEN, Bard E, Bayliss A, Blackwell P, Bronk Ramsey C, Butzin M, Edwards L, Friedrich M, Grootes PM, Guilderson T, Hajdas I, Heaton T, Hogg AG, Hughen KA, Kromer B, Manning SW, Muscheler R, Palmer J, Pearson C, van der Plicht J, Reimer RW, Richards D, Scott EM, Southon JR, Turney CSM, Wacker L, Adophi F, Büntgen U, Capano M, Fahrni S, Fogtmann-Schulz A, Friedrich R, Köhler P, Kudsk S, Miyake F, Olsen J, Reinig F, Sakamoto M, Sookdeo A, Talamo S. The IntCal20 northern hemisphere radiocarbon calibration curve (0-55 kcal BP). Radiocarbon. 2020;62:725-57.

51. Mook WG. Introduction to Isotope Hydrology. London: Taylor and Francis; 2006.

52. Hong D, Kim M, Choi J, El-Faramawy N, Göksu H. Equivalent dose determination of single aliquot regenerative-dose (SAR) protocol using thermoluminescence on heated quartz. Nucl Instr Meth Phys Res Sec B: Beam Interactions with Materials and Atoms. 2006;243:174-8.

53. Kreutzer S, Schmidt C, Fuchs MC, Dietze M, Fischer M, Fuchs M. Introducing an $\mathrm{R}$ package for luminescence dating analysis. Ancient TL. 2012;30:1-8.

54. Olley J, Caitcheon G, Murray A. The distribution of apparent dose as determined by optically stimulated luminescence in small aliquots of fluvial quartz: Implications for dating young sediments. Quatern Sci Rev. 1998;17:1033-40. https://doi.org/10.1016/s0277-3791(97)00090-5.

55. Liritzis I, Kitis G, Galloway RB, Vafiadou A, Tsirliganis N, Polymeris G. Probing luminescence dating of archaeologically significant carved rock types. Med Archaeol Archaeom. 2008;8:61-79.

56. Grün R. The DATA program for the calculation of ESR age estimates on tooth enamel. Quat Geochronol. 2009;4:231-2. https://doi. org/10.1016/j.quageo.2008.12.005

57. Gratuze B. Obsidian characterization by laser ablation ICP-MS and its application to prehistoric trade in the Mediterranean and the Near East: Sources and distribution of obsidian within the Aegean and Anatolia. J Archaeol Sci. 1999;26:869-81.

58. Colombini MP, Modugno F, Riberchini E. Organic mass spectrometry in archaeology: evidence for Brassicaceae seed oil in Egyptian ceramic lamps. J Mass Spec. 2005;40:890-8.

59. Kramer JKG. High and Low Erucic Acid in Rapeseed Oils. New York: Academic Press; 2012.
60. Mathe C, Culioli G, Archier P, Vieillescazes C. Characterization of archaeological frankincense by gas chromatography-mass spectrometry. J Chrom A. 2004;1023:277-85.

61. Simon-Delso N, Amaral-Rogers V, Belzunces LP, et al. Systemic insecticides (neonicotinoids and fipronil): trends, uses, mode of action and metabolites. Environ Sci Pollut Res. 2015;22:5-34. https://doi. org/10.1007/s11356-014-3470-y.

62. Rasmussen KL, Boldsen JL, Kristensen HK, Skytte L, Hansen KL, Mølholm L, Grootes PM, Nadeau M-J, Eriksen KMF. Mercury levels in Danish Medieval human bones. J Archaeol Sci. 2008;35:2295-306.

63. Alvarez-Fernandez N, Martinez-Cortizas A, Lopez-Costas O. Atmospheric mercury pollution deciphered through archaeological bones. J Archaeol Sci. 2020;119:105159.

64. Rasmussen KL, Torino M, Glastrup J, Ramseyer NT, Bjerregaard P. On the embalmment of S. Francesco Caracciolo Archaeometry. 2012;54:1100-13.

65. Rasmussen KL, Kučera J, Skytte L, Kamenik J, Havranek V, Smolik J, Veleminsky P, Lynnerup N, Bruzek J, Vellev J. Was he murdered or was he not? - Part l: Analyses of mercury in the remains of Tycho Brahe. Archaeometry. 2013;55:1187-95.

66. Kučera J, Rasmussen KL, Kamenik J, Kubesova M, Skytte L, Povysil C, Karpenko V, Havranek V, Veleminsky P, Lynnerup N, Bruzek J, Smolik J, Vellev J. Was he murdered or was he not? - Part II: Multi-element analyses of hair and bone samples from Tycho Brahe and histopathology of his bones. Archaeometry. 2017;59:918-33.

67. Charlier P. Qui a tué la Dame de Beauté? Étude scientifique des restes d'Agnès Sorel (1422-1450). Hist Sci Med. 2006;40:255-63.

68. Alexandrovskaya E, Panova T. History of the soil, cultural layer, and people in medieval Moscow. Rev Mex Cienc Geol. 2003;20:289-94.

69. Alexandrovskaya E, Alexandrovskiy A. Radiocarbon data and anthropochemistry of ancient Moscow. Geochronometria. 2005;24:87-95.

70. Panova TD. Kremlin Tombs: History, destinies, and mysteries. Moscow: Indrik (printer). 2003:224. ISBN 5-85759-233-X.

71. Fornaciari G, Marinozzi S, Gazzaniga V, Giuffra V, Picchi MS, Giusiani M, Masetti M. The use of mercury against pediculosis in the Renaissance: the case of Ferdinand II of Aragon, King of Naples, 1467-96. Med Hist. 2011;55:109-15.

72. Brown AB. Bone strontium as a dietary indicator in human skeletal populations. Rocky Mountain Geol. 1974;13:47-8.

73. Schutkowski H, Herrmann B, Wiedemann F, Bocherens H, Grupe G. Diet, status and decomposition at Weingarten: Trace element and isotope analyses on early mediaeval skeletal material. J Archaeol Sci. 1999;26:675-85.

74. Fabig H. Skeletmaterial Validitätserwägungen im Kontext diagenetisch bedingter Konzentrationsänderungen des Knochenminerals. Ph.D. thesis, Georg-August-Universität zu Göttingen. 2002.

75. Skytte L, Rasmussen KL. Sampling strategy and analysis of trace element concentrations by Inductively Coupled Plasma Mass Spectroscopy on medieval human bones - the concept of chemical life history. Rapid Com Mass Spec. 2013;27:1591-9.

76. Lösch S, Moghaddam N, Grossschmidt K, Risser DU, Kanz F. Stable Isotope and Trace Element Studies on Gladiators and Contemporary Romans from Ephesus (Turkey, 2nd and 3rd Ct. AD)_implications for differences in diet. PLOS ONE. 2014;9:e1 10489.

77. Torino M, Boldsen JL, Tarp P, Rasmussen KL, Skytte L, Nielsen L, Schiavone S, Terrasi F, Passariello I, Ricci P, Lubritto C. Convento di San Francesco a Folloni: the function of a Medieval Franciscan Friary seen through the burials. Herit Sci. 2015;3:27.

78. Rasmussen KL, Delbey T, d'Imporzano P, Skytte L, Schiavone S, Torino M, Tarp P, Thomsen PO. Comparison of trace element chemistry in human bones interred in two private chapels attached to Franciscan friaries in Italy and Denmark: an investigation of social stratification in two medieval and post-medieval societies. Herit Sci. 2020;8:65.

79. Rasmussen KL, Gwozdz R, Taylor J, Doudna G. Preliminary data of trace element concentrations in Qumran human bone samples. In: Khirbet Qumrân et'Ain Feshkha II (eds Humbert J-B, Gunneweg J). Academic Press Fribourg, Vandenhoeck \& Ruprecht Göttingen. 2003;185-189.

80. Rasmussen KL, Milner GM, Delbey T, Skytte L, Søvsø M, Callesen F, Boldsen JL. Copper exposure in medieval and post-medieval Denmark and northern Germany: its relationship to residence location and social position. Herit Sci. 2020;8:18 
81. Rogers J, Waldron T. Lead concentrations in bones from a Neolithic long barrow. J Archaeol Sci. 1985;12:93-6.

82. Özdemir K, Erdal YS, Demirci S. Arsenic accumulation on the bones in the Early Bronze Age Ikiztepe Population. Turkey J Archaeol Sci. 2010;37:1033-41.

83. Gilbert RI. Applications of trace element research to problems in archaeology. In: Biocultural adaptation in prehistoric America (ed. Blakely RL). Southern Anthropological Society Proceedings 11. Athens: University of Georgia Press. 1977:85-100.

84. Byrne KB, Parris DC. Reconstruction of the diet of the middle Woodland Indian population at Abbott Farm by bone trace-element analysis. Am J Phys Anthropol. 1987;74:373-84.

85. Buikstra JE, Frankenberg S, Lambert JB, Xue L. Multiple elements: multiple expectations. In: Price TD, editor. The chemistry of prehistoric human bone. Cambridge: Cambridge University Press; 1989. p. 155-210.

86. Arrhenius B. Trace element analyses of human skulls. Laborativ Arkeologi. 1990;4:15-9.

87. Allmäe R, Limbo-Simovart J, Heapost L, Verš E. The content of chemical elements in archaeological human bones as a source of nutrition research. Papers Anthropol. 2012;21:27-49.

88. Klepinger LL. Nutritional assessment from bone. Ann Rev Anthropol. 1984;13:75-96.

89. Rasmussen KL, Milner GR, Delbey T, Skytte L, Lynnerup N, Thomsen JL, Schiavone S, Torino M, Larsen LA, Boldsen JL. Trace element distribution in human cortical bone microstructure - the potential for unravelling diet and social status in archaeological bones. Submitted to Herit Sci.

90. Fry B. Stable isotope ecology. Springer. ISBN 0-387-30513-0. 2008.

91. Hedges REM, Reynard LM. Nitrogen isotopes and the trophic level of humans in archaeology. J Archaeol Sci. 2007;34:1240-51.
92. Lanting JN, van der Plicht J. Reservoireffects and apparent ${ }^{14} \mathrm{C}$ ages. J Irish Archaeol. 1998;9:151-65.

93. Philippsen B. The freshwater reservoir effect in radiocarbon. Herit Sci. 2013;1:24.

94. Bocherens H, Mashkour M, Drucker DG, Moussa I, Billiou D. Stable isotope evidence for paleodiets in southern Turkmenistan during Historical period and Iron Age. J Archaeol Sci. 2006;33:253-64.

95. Fuller BT, Fuller JL, Harris DA, Hedges REM. Detecting of breastfeeding and weaning in modern human infants with carbon and nitrogen stable isotope ratios. Am J Phys Anthropol. 2006;129:279-93.

96. Volp U. Tod und Ritual in den christlichen Gemeinden der Antike. SVigChr 65. Leiden and Boston. 2002.

97. Jensen RM. Saints, Relics and the Consecration of Church Buildings in Rome. In: Studia Patristica (eds. Day J, Vinzent M). 2012;LXXI:153-169.

98. Kötting B. Der frühchristliche Reliquienkult und die Bestattung im Kirchengebäude. Wiesbaden. 1965. p. 17.

99. Theodorus Lector, Hist. eccl. 2.61-65.

100. Brakke D. Outside the Place, within the Truth: Athanasius of Alexandria and the Localization of the Holy. In: Pilgrimage and Holy Space in Late Antique Egypt (ed. Frankfurter D). Brill, Leiden. 1998. p. 446-481.

101. Frankfurter D. Beyond Magic and Superstition. In: Late Antique Christianity (ed. Burrus V). Fortress, Minneapolis. 2005. p. 255-282.

\section{Publisher's Note}

Springer Nature remains neutral with regard to jurisdictional claims in published maps and institutional affiliations.

\section{Submit your manuscript to a SpringerOpen ${ }^{\circ}$ journal and benefit from:}

- Convenient online submission

- Rigorous peer review

- Open access: articles freely available online

- High visibility within the field

- Retaining the copyright to your article

Submit your next manuscript at $\boldsymbol{\sim}$ springeropen.com 